\title{
NEPOTIZMUS V SPRÁVE SPIŠSKEJ STOLICE V ROKOCH 1711 - 1785
}

\section{TOMÁŠ J A N U R A}

JANURA, Tomáš. Nepotism in the administration of the County of Spiš in the period 1711 - 1785. Historický časopis, 2020, 68, 3, pp. 409-437, Bratislava.

The study is devoted to the creation of nepotistic ties between individual officials in the administration of the County of Spiš (Comitatus Scepusiensis, Szepes vármegye, Zipser Gespannschaft, Spišská stolica). In comparison with the County of Liptov, the ties between officials in Spiš were usually not on the level of cousin, uncle, nephew, son-in-law, brother-inlaw or god-son. On the basis of the surviving registers, it is possible to conclude that the system of ecclesiastical officials also did not develop in Spiš in a similar way to that in Liptov. These phenomena were clearly connected with the lack of a firm marriage alliance between the Görgey and Máriássy families, which were comparable to the two firmly allied Liptov families: the Okolicsányis and Szentiványis. The only deputy sheriff of Spiš to systematically build up a network of relations was Stephen Máriássy.

Key words: Nepotism. Clientelism. County of Spiš. Máriássy Family. Görgey Family.

DOI: https://doi.org/10.31577/histcaso.2020.68.3.2

K dôležitým aspektom l'udskej spoločnosti raného novoveku patrila snaha jednotlivca začlenit' sa do väčšieho spoločenstva, ktoré mu mohlo priniest' upevnenie vlastného postavenia či zlepšenie podmienok pre svojich potomkov. Preto sa nemožno čudovat', že sa prirodzenou l'udskou vlastnost'ou stalo vytváranie siete kontaktov na základe príbuzenských, konfesionálnych či priatel'ských väzieb. $\mathrm{V}$ radoch privilegovaného obyvatel'stva Uhorska sa posilňovanie spojenia s ostatnými členmi šl'achtickej vrstvy pretavilo okrem iného aj do premyslených sobášnych stratégií za účelom upevnenia si sociálnych, ekonomických a mocenských pozícií. V uhorských stoliciach sa preto hojne využíval nepotizmus ako prostriedok niektorých rodov, ktorým si zaist’ovali vplyv na fungovanie konkrétnej administratívnej jednotky.

$\mathrm{V}$ prípade predkladaného textu podobne ako $\mathrm{v}$ predošlých publikovaných štúdiách ${ }^{1}$ sledujem vytváranie nepotizmu na príklade riadnych podžupanov ako

1 JANURA, Tomáš. Nepotizmus v správe Liptovskej stolice v 18. storočí. In Historický časopis, 2011, roč. 58, č. 3, s. 403-426. ISSN 0018-2575; JANURA, Tomáš. Uhorské stolice 
najvyšších volených predstavitel'ov stolíc. Riadni podžupani sa totiž snažili, aby pri vol'bách alebo menovaniach úradníkov získali medzi podriadenými svojich „rodinných“ úradníkov. Pod týmto termínom mám na mysli tých šlachticov, ktorí boli v bližšom či vzdialenejšom stupni pokrvnými podžupanovými príbuznými. V minulosti sa vel'ký význam prikladal sviatosti krstu, a preto môžeme aj „duchovných“ úradníkov považovat' za členov nepotistickej siete. Pod takýmto označením chápem privilegovaných mužov, tvoriacich najbližších pokrvných príbuzných šlachtica alebo šlachtičnej, ktorých krstným otcom bol riadny podžupan a krstnou matkou podžupanova manželka.

Výskum nepotizmu v uhorských stoliciach si vyžiadal niekol'ko podmienok na realizáciu. $\mathrm{V}$ prvom rade musel prebehnút' výskum personálneho obsadenia jednotlivých postov. V druhom slede sa opieral o publikované genealogické práce, bez ktorých by sa nedali rekonštruovat' spletité príbuzenské väzby. Ked’že k nie všetkým administratívne aktívnym rodom vyšli potrebné údaje, nutne sa musela urobit' dodatočná rešerš v matrikách. Z nich sa doplnili aj údaje o krstných rodičoch detí, ked’že ich genealogické práce neuvádzali. $Z$ uvedených dôvodov preto neprekvapuje, že $\mathrm{k}$ téme nepotizmu $\mathrm{v}$ stoliciach $\mathrm{v}$ období 18 . storočia nevznikli skoro žiadne práce s výnimkou už publikovaných štúdií Tomáša Januru a Istvána Szijártóa. ${ }^{2}$

Ako hraničné roky som si zvolil rok 1711, ked' sa celé územie Spišskej stolice dostalo spod kontroly povstalcov Františka II. Rákócziho, a rok 1785, ked' sa zaviedli do praxe správne reformy Jozefa II. No napriek tomu došlo k istým časovým presahom, ked’že riadny podžupan Imrich Horváth-Stansith bol vo funkcii už od roku 1709. Údaje z roku 1790 mali poukázat' na klesajúci vplyv nepotizmu, ako to bolo v prípade Liptovskej stolice. Vymedzené rozpätie predstavuje dostatočne vel'ký časový úsek na vyvodenie všeobecnejších záverov na konkrétnom príklade Spišskej stolice. Vyslovené tvrdenia som však zatial' pre nedostatok podobne zameraných štúdií mohol porovnávat' iba s publikovanými údajmi z Liptovskej a Oravskej stolice.

Vnútorne som prácu rozčlenil podl’a jednotlivých funkčných období riadnych podžupanov a pri hodnotení podielu „rodinných“ a „duchovných“ úradníkov som vychádzal iba z výsledkov volieb, ktoré sa konali v čase zastávania úradu daným podžupanom. Z percentuálnych hodnotení som vynechal iba volených

v zajatí nepotizmu a klientelizmu. In ŠOLTÉS, Peter - VÖRÖS, Ladislav et al. Korupcia. Bratislava: Historický ústav SAV, 2015, s. 56-99. ISBN 978-80-224-1447-0.

2 SZIJÁRTÓ, István. Hivatalviselő elit a 18. századi Somogy vármegyében. In HERMANN, István - KARLINSZKY, Balázs (Eds.). Megyetörténet: Egyház- és igazgatástörténeti tanulmányok a veszprémi püspökség 1009. évi adománylevele tiszteletére. Veszprém: Veszprémi érseki és fơkáptalani levéltár, Veszprém megyei levéltár, 2010, s. 445-466. ISBN 978-9637229-20-6. 
komisárov, pretože záznamy o ich vol'bách sa neviedli presne a aj genealogické údaje ku konkrétnym komisárom boli vel'mi medzerovité. Záverečnú čast' som venoval vol'bám v roku 1790, ked'sa definitívne potvrdil trend oslabenia vplyvu nepotizmu riadnych podžupanov.

\section{Obdobie riadneho podžupana Imricha Horvátha-Stansitha (1709 - 1712)}

Imricha Horvátha-Stansitha ako predstavitel'a najbohatšieho spišského rodu zvolili do funkcie podžupana niekedy v priebehu roku $1709^{3}$ za povstania Františka II. Rákócziho. Za menovaním, respektíve zvolením nového podžupana stála jeho neochvejná evanjelická viera augsburského vyznania, ked’že príslušníci tejto konfesie na Spiši tvorili podstatnú čast' nobility. Istú úlohu pri jeho zvolení mohol zohrávat' aj fakt, že Horváthovci-Stansithovci na rozdiel od d’alších dvoch významných rodov Görgey a Máriássy vyznávali výlučne evanjelickú vieru a neboli konfesionálne rozdelení. $\mathrm{K}$ zisku postu $\mathrm{v}$ čase povstania prispela skutočnost', že v roku 1706 ako kapitán velil insurekčnému vojsku namierenému proti cisárskej armáde. ${ }^{4}$

Imrich Horváth-Stansith na rozdiel od Liptovskej stolice vo svojej funkcii pokračoval aj potom, ako územie Spiša obsadilo cisárske vojsko a vytlačilo povstalcov d’alej na východ. Imrich totiž 13. decembra 1709 dostal osvedčenie od generála Heistera o vernosti panovníkovi a pri vol'bách 13. júla 1711 ho stavy potvrdili na predošlej pozícii. Z hl'adiska náboženského vierovyznania evanjelici obsadili devät' postov, čo predstavovalo $60 \%$ podiel zo všetkých volených úradov. ${ }^{5}$

3 Presný dátum zvolenia alebo menovania do funkcie nebolo možné zistit', ked’že kongregačné protokoly z tohto roku sa nezachovali v kompletnosti alebo boli výrazne poškodené v priebehu povstania.

4 Ministerstvo vnútra Slovenskej republiky (d’alej MV SR), Spišský archív v Levoči (d’alej SAL), fond (d’alej f.) Spišská župa (d’alej SŽ), inventárne číslo (d’alej i. č.) 62, kongregačný protokol (d’alej KP) z rokov 1709 - 1711, kartón (d’alej k.) 22, pagina (d’alej pag.) 41; FÓNAGY, Zoltán. A nemesi birtokviszonyok az úrbérrendezés korában. Budapest: MTA Bölcsészettudományi Kutatóközpont Történettudományi Intézet, 2013, s. 1012. ISBN 978-9639627-59-8; JANURA, Tomáš - HAVIAROVÁ, Michaela. Vidiecke šlachtické sídla v Spišskej stolici. Bratislava: Spoločnost' Kolomana Sokola, 2019, s. 124. ISBN 978-80-89756-16-2; SZLUHA, Márton. Szepes vármegye nemes családjai. Budapest: Heraldika Kiadó, 2013, s. 98-125, 151-153, 231-251. ISBN 978-963-920-479-9.

5 MV SR, SAL, f. SŽ, i. č. 63, KP z rokov 1711 - 1713, k. 22, pag. 28, 29; f. Zbierka cirkevných matrík (d’alej ZCM), i. č. 1, matrika rímsko-katolíckej farnosti (d’alej MRKF) Abrahámovce, k. 1, pag. 611, 635; i. č. 25, MRKF Brutovce, k. 9, pag. 133, 137; i. č. 139, MRKF Huncovce, k. 59, pag. 29, 35; i. č. 618, MRKF Slovenská Ves, k. 231, pag. 105; i. č. 707, MRKF Spišská Kapitula, k. 269, pag. 227; i. č. 829, MRKF Spišský Hrhov, k. 319, pag. 86; JANURA - HAVIAROVÁ, ref. 4, s. 124; SZLUHA, ref. 4, s. 102, 113, 114, 152, 358. 
Percentuálna prevaha evanjelikov sa ale neprejavila aj v rovine nepotizmu, ked’že podiel „rodinných“ úradníkov predstavoval šest’ šlachticov, t. j. 42,86 \%. Pri dosiahnutí nižšieho čísla zohrali svoju úlohu viaceré faktory. Otec Imricha Horvátha-Stansitha sa totiž v priebehu 17. storočia vôbec neangažoval v stoličnej správe. Rovnako samotný Imrich v predošlom období v rokoch $1682-1683$ zastával post slúžneho prvého okresu a v krátkom čase rokov 1699 - 1701 bol zastupujúcim podžupanom. Imrich teda ,nezdedil“ funkciu riadneho podžupana po otcovi a zrejme ani sám neuvažoval o dlhodobej stoličnej kariére, ked’že ako držitel' panstva Strážky a majitel' viníc v Tokaji nebol odkázaný na príjmy z úradníckej alebo súdnickej činnosti. $Z$ uvedeného dôvodu ani premyslene nebudoval prostredníctvom sobášnej politiky siet' spriaznených úradnícky aktívnych rodov. V skutočnosti tak získaný podiel „rodinných“ úradníkov vychádzal len z dosial” uzavretých zväzkov. ${ }^{6}$

Z úzkeho rodinného prepojenia sa podarilo obsadit' oba notárske posty a funkciu jedného slúžneho. Na post riadneho notára zvolili v júli 1711 Gabriela Pálfalvaya, ktorého manželka bola neterou svokra Imricha Horvátha-Stansitha. Zastupujúci notár Žigmund Görgey bol synovcom Imrichovho svokra Andreja st. Székelyho. V prvom okrese zvolili za riadneho slúžneho podžupanovho švagra Andreja ml. Székelyho. Vzdialenejšie príbuzenstvo predstavoval riadny slúžny v druhom okrese Ladislav Görgey, ktorého švagor Štefan Okolicsányi bol bratrancom Jána Okolicsányiho, pričom Ján bol svokrom podžupanovej sesternice Anny Horváthovej-Stansithovej. Zastupujúcim slúžnym tretieho okresu sa stal Štefan Horváth-Mladosevith, ktorého dcéra bola švagrinou Ladislava Okolicsányiho, pričom Ladislav bol starým otcom manžela podžupanovej sesternice Anny Horváthovej-Stansithovej. Za prísažného druhého okresu určili brata Ladislava Görgeya Štefana Görgeya.

Na druhej strane by bolo možné uvažovat' o tom, či by Imrich Horváth-Stansith začal budovat' siet' svojich úradníkov, keby počas rokovania snemu v Bratislave 7. septembra 1712 nezomrel. Ak by zotrval vo svojej funkcii, v dôsledku rekatolizácie by zrejme musel odstúpit', ked’že príslušníci jeho rodu nikdy nekonvertovali k rímsko-katolíckej viere, aby si uchovali svoje postavenie v správe Spišskej stolice. ${ }^{7}$

\section{Obdobie riadneho podžupana Františka st. Görgeya (1712 - 1716)}

Po smrti Imricha Horvátha-Stansitha nedávno inštalovaný hlavný župan gróf Žigmund Csáky nezvolal okamžite stavy, aby sa určil nový riadny podžupan,

6 MV SR, SAL, f. SŽ, i. č. 41, KP z rokov 1680 - 1683, k. 12, pag. 161, 286; i. č. 54, KP z rokov 1699 - 1701, k. 18, pag. 13; i. č. 55, KP z rokov 1701 - 1703, k. 18, pag. 9; JANURA - HAVIAROVÁ, ref. 4, s. 123-125.

7 SZLUHA, Márton. Liptó vármegye nemes családjai. Budapest: Heraldika Könyvkiadó, 2000, s. 438-441. ISBN 978-963-856-452-8; SZLUHA, ref. 4, s. 112-114, 152, 153, 358. 
ako bývalo v stoliciach zvykom. Zrejme chcel zabránit', aby na post znovu zvolili evanjelika, a preto hned' $v$ septembri 1712 priamo vymenoval do funkcie katolíka Františka st. Görgeya. Zo strany Csákyho išlo svojím spôsobom aj o kompromisné riešenie, ked’že predpokladal jeho akceptáciu v dôsledku toho, že šlo o starý stredoveký spišský rod a jeho príslušníci sa konfesionálne delili medzi stúpencov rímsko-katolíckej i evanjelickej viery augsburského vyznania.

Najbližšia reštaurácia sa konala až $\mathrm{s}$ takmer ročným odstupom 22. augusta 1713 a miestne stavy potvrdili napriek vysokému veku (asi 68 rokov) Františka st. Görgeya ako svojho riadneho podžupana. Ked’že sa predpokladalo, že Görgey nebude môct' plnohodnotne vykonávat' svoje povinnosti, ako zastupujúceho podžupana zvolili pomerne mladého, asi 26-ročného Krištofa Mersze zo Svinej. Navyše vol'bou zastupujúceho podžupana sa porušilo nepísané pravidlo, že úradník by mal vlastnit' majetok v danej stolici, pričom Mersze pochádzal zo susednej Šarišskej stolice. Pri Merszeho vol'be však zavážilo, že bol zat'om Görgeya, čím sa oba podžupanské posty ocitli v rukách jednej rodiny. Preferenciu katolíckej viery vo vol'bách odrážala aj skutočnost', že oproti predošlému obdobiu zvolili už len štyroch evanjelických šlachticov, čo predstavovalo $25 \%$. Rovnaký pomer oboch vierovyznaní sa udržal aj pri d’alších vol'bách 1 . októbra $1715 .{ }^{8}$

Z hl'adiska budovania nepotizmu mal František st. Görgey priaznivé i nepriaznivé predpoklady vybudovat' základy budúcej dynastie. K nepriaznivým okolnostiam sa radil jeho vy̌šśi vek, čo spôsobilo, že už nemohol ovplyvnit' sobášne stratégie svojho dospelého potomstva žijúceho už v manželských zväzkoch a navyše s predstavitel'mi nespišských rodov. Görgey síce v rokoch 1698 - 1703 zastával post spišského podžupana, ale už v roku 1703 rezignoval pre zhoršujúcu sa podagru. Ďalej ani jeho otec a starý otec nikdy neobsadili podžupanské miesto. Na druhej strane, výhodou Görgeya bolo, že sa stal švagrom Baltazára Görgeya, podžupana Spišskej stolice v rokoch $1684-1698 .{ }^{9}$

Napriek uvedeným znevýhodneniam sa vd’aka príbuzenstvu s Baltazárom Görgeyom podarilo Františkovi st. Görgeyovi v roku 1713 dosiahnut’ 66,67 \% podiel „rodinných“ úradníkov. Okrem spomínaného Františkovho zat’a Krištofa Merszeho zvolili za riadneho notára Gabriela Pálfalvaya, ktorého otec bol s vel'-

8 MV SR, SAL, f. SŽ, i. č. 64, KP z rokov 1713 - 1715, k. 23, pag. 4; f. ZCM, i. č. 9, matrika evanjelickej farnosti (d’alej MEF) Batizovce, k. 4, pag. 257; i. č. 25, MRKF Brutovce, k. 9, pag. 133; i. č. 619, MRKF Slovenská Ves, k. 231, pag. 138; i. č. 339, MRKF Levoča, k. 129, pag. 113; i. č. 707, MRKF Spišská Kapitula, k. 269, pag. 227, 253; i. č. 829, MRKF Spišský Hrhov, k. 319, pag. 86; i. č. 841, MRKF Spišský Hrušov, k. 322, pag. 82, 152; SZLUHA, Márton. Felvidéki nemes családok II.: Sáros megye. [CD-ROM]. Budapest: Heraldika Könyvkiadó, 2006, Berzeviczy, Berzeviczei és Kakaslomniczi nemes és †báró, tabul'ka II, Semsey, Semsei nemes és gróf, tabul'ka II, Szinyei Merse (Merse), Szinyei, tabul'ka II. ISBN 978-963-920-446-1; SZLUHA, ref. 4, s. 124.

9 MV SR, SAL, f. SŽ, i. č. 43, KP z rokov $1684-1686$, k. 12, pag. 9; i. č. 52, KP z rokov $1698-1699$, k. 15, pag. 6; i. č. 57, KP z roku 1703, k. 19, pag. 13; SZLUHA, ref. 4, s. 102. 
kou pravdepodobnost'ou švagrom Františka st. Na dôvažok Gabriel Pálfalvay patril medzi klientov samotného hlavného župana Žigmunda Csákyho, čím sa obojstranne posilnilo postavenie župana i podžupana. Podnotárom sa stal Žigmund Görgey, ktorého otec bol bratrancom zata Františka st. Görgeya. Z centrálnych úradov sa pod kontrolu riadneho podžupana dostal aj fiškál Žigmund Theöke, ktorý bol švagrom manželky Františka st. ${ }^{10}$

Františkovi st. Görgeyovi sa podarilo jeho príbuznými na lokálnej úrovni obsadit' celý prvý okres. Manželka riadneho slúžneho Mikuláša Semseya bola neterou manželky Františka st. Z pokrvne vzdialenejších príbuzných za prísediacich prvého okresu zvolili Baltazára Berzeviczyho, ktorého neter bola manželkou Žigmunda Görgeya, a L’udovíta Mattyasovszkého, ktorého sestra bola švagrinou otca Žigmunda Görgeya. V druhom okrese jednu z funkcií prísažného obsadil Štefan Görgey, pričom otec jeho švagra bol švagrom Františka st. V tret'om okrese sa prísažnými stali Andrej Theőke, ktorý bol druhostupňovým bratrancom Žigmunda Theőkeho a krstným otcom dcéry novozvoleného prísažného Jána Ugróczyho bol Gabriel Pálfalvay. ${ }^{11}$

Vo funkčnom období Františka st. Görgeya sa konali vol'by ešte 1. októbra 1715 , pričom sa udržali štyria evanjelici, čím sa dosiahlo $25 \% \cdot{ }^{12}$ Ked’že riadny podžupan mal iba obmedzené možnosti na budovanie nepotizmu, podiel jeho „rodinných“ úradníkov sa z desiatich znížil na sedem, čo predstavovalo 46,67 \%. No napriek tomu pod jeho kontrolu pripadli z administratívneho hl'adiska dôležitejšie ústredné pozície. Na stoličke zastupujúceho podžupana zostal Krištof Mersze, riadneho notára Gabriel Pálfalvay, podnotára Žigmund Gögey a fiškála Žigmund Theőke. Na miestnej úrovni si svoje predošlé úrady udržal riadny slúžny prvého okresu Mikuláš Semsey a prísažný tretieho okresu Andrej Theőke. Prísažného v prvom okrese Baltazára Berzeviczyho vystriedal Štefan Berzeviczy, ktorého svokra bola tetou Žigmunda Görgeya.

Absencia systematického budovania siete nepotizmu zo strany Františka st. Görgeya sa podpísala na skutočnosti, že po jeho smrti jeho syn a ani vnukovia nedosiahli žiadne posty v správe Spišskej stolice. Navyše, Františkovým vnukom v roku 1741 úplne vymrelo jeho mužské potomstvo. ${ }^{13}$

10 SZLUHA, ref. 4, s. 102, 113, 124, 392; SZLUHA, ref. 7, s. 623, 635.

11 MV SR, SAL, f. ZCM, i. č. 707, MRKF Spišská Kapitula, k. 269, pag. 253; SZLUHA, ref. 4, s. 102, 103, 112-114, 124, 265, 392, 393; SZLUHA, ref. 8, Berzeviczy, Berzeviczei és Kakaslomniczi nemes és †báró, tabul'ka II; Semsey, Semsei nemes és gróf, tabul'ka II.

12 MV SR, SAL, f. SŽ, i. č. 64 , KP z rokov $1713-1715$, k. 23, pag. 387, 388; f. ZCM, i. č. 10 , MEF Batizovce, k. 4, pag 289; i. č. 618, MRKF Slovenská Ves, k. 231, pag. 117; i. č. 799, MRKF Spišské Podhradie, k. 307, pag. 357; i. č. 849, MRKF Spišský Štvrtok, k. 326, pag. 308; SZLUHA, ref. 8, Berzeviczy, Berzeviczei és Kakaslomniczi nemes és †báró, tabul'ka VI.

13 SZLUHA, ref. 4, s. 113, 124, 358; SZLUHA, ref. 8, Berzeviczy, Berzeviczei és Kakaslomniczi nemes és †báró, tabul'ka VI. 


\section{Obdobie riadneho podžupana Krištofa Merszeho (1720 - 1725)}

Po smrti Františka st. Görgeya 10. mája 1716 hlavný župan Žigmund Csáky vôbec nezvolal nové vol'by, ako bolo zvykom po úmrtí riadneho podžupana. Navyše ani nevyužil svoje právo priamo menovat' nového, hoci župani v Uhorsku bežne po úmrtí niektorého z úradníkov vymenovali vzápätí náhradníka do najbližšej reštaurácie. Kompetencie riadneho podžupana teda na obdobie štyroch rokov úplne prevzal zastupujúci podžupan Krištof Mersze. Stavy sa na postup Csákyho nest'ažovali, čo zrejme súviselo s tým, že kompetencie sa vlastne akoby dedične preniesli zo svokra na zat’a. ${ }^{14}$

Do funkcie riadneho podžupana stavy zvolili katolíka Krištofa Merszeho až potom, ako hlavný župan ustanovil termín reštaurácie na 18. júna 1720. Východiskovú Krištofovu pozíciu na budovanie nepotizmu negatívne ovplyvňovalo, že pochádzal z vedl’ajšej Šarišskej stolice a na území Spiša mal iba skromné majetky vo Vyšnom Slavkove. V tomto ohl'ade tesne pred vol'bami Krištofov majetkový status zmenil brat Žigmunda Csákyho kardinál Imrich Csáky, ktorý 1. júna 1720 založil Krištofovi za 800 zlatých kúriu v Spišskom Hrušove. Počas volieb sa posilnila pozícia evanjelikov, ked' z pätnástich funkcií obsadili sedem postov, teda $46,7 \% .^{15}$

Zvýšený podiel evanjelikov sa priamo odrazil aj v znížení percentuálneho podielu „rodinných“ úradníkov o $10 \%$ na $35,71 \%$ oproti vol’bám z roku 1715. Situáciu spôsobilo, že otec a ani starý otec Krištofa Merszeho nikdy nepôsobili v správe Spišskej stolice a aj samotný Krištof sa na post zastupujúceho podžupana dostal len vd'aka skutočnosti, že bol zat'om Františka st. Görgeya. Ked’že potomstvo Františka st. Görgeya sa vôbec neangažovalo v správe, z hl'adiska zachovania istého podielu „rodinných“ úradníkov tak klúčovú úlohu pre Merszeho zohral novozvolený zastupujúci podžupan a zároveň slúžny druhého okresu Štefan Görgey. Sestra Štefana Görgeya bola švagrinou Alžbety Merszeovej, ktorá bola Krištofovou sesternicou. Slúžnym prvého okresu sa stal L'udovít Mattyasovszky, ktorého sestra bola tetou Štefana Görgeya. Post prísažného notára obsadil bratranec Štefana Görgeya Žigmund Görgey a prísažného a výbercu daní v prvom okrese L'udovít Görgey, pričom švagor Ludovítovho otca Pavol Görgey bol strýkom Štefana Görgeya. ${ }^{16}$

14 SZLUHA, ref. 4, s. 124.

15 MV SR, SAL, f. SŽ, i. č. 48, KP z rokov 1720 - 1721, k. 24, pag. 1-4; f. ZCM, i. č. 9, MEF Batizovce, k. 4, pag. 257; i. č. 10, MEF Batizovce, k. 4, pag. 289; i. č. 15, MRKF Bijacovce, k. 7, pag. 12; i. č. 25 , MRKF Brutovce, k. 9, pag. 160; i. č. 251, MEF Kežmarok, k. 99, pag. 41, 46; i. č. 339, MRKF Levoča, k.129, pag. 113; i. č. 617, MRKF Slovenská Ves, k. 231, pag. 49; i. č. 829, MRKF Spišský Hrhov, k. 319, pag. 829; JANURA - HAVIAROVÁ, ref. 4, s. 135; SZLUHA, ref. 4, s. 48, 49, 100, 306, 322; SZLUHA, ref. 8, Szinyei Merse (Merse), Szinyei, tabul'ka II.

16 SZLUHA, ref. 4, s. 101, 102, 113, 114, 124, 265; SZLUHA, ref. 8, Szinyei Merse (Merse), 
Koniec kariéry podžupana $\mathrm{v}$ prípade Krištofa Merszeho na rozdiel od ostatných nespôsobilo jeho úmrtie, ale z hl'adiska úradníckej kariéry získanie lukratívnejšieho postu provinčného komisára so sídlom v Levoči. Výkon novej funkcie sa nezlučoval s nedávno zavedenými pravidlami o zákaze vykonávania dvoch úradov súčasne v rôznych administratívnych jednotkách. Provinčné komisariáty zriadila dynastia a pri výbere daní predstavovali pre stolice nadriadenú inštitúciu. Krištofa vymenovali za provinčného komisára niekedy v prvej polovici roku 1725 , a preto sa počas júlových volieb vzdal d’alšej kandidatúry. ${ }^{17}$

\section{Obdobie riadneho podžupana Žigmunda Görgeya (1725 - 1731)}

Po nutnosti abdikácie Krištofa Merszeho bol 23. júla 1725 v prítomnosti hlavného župana Žigmunda Csákyho určený za nového riadneho podžupana niekdajší notár a katolík Žigmund Görgey. K jeho zvoleniu prispela aj skutočnost', že Görgeyovi prvostupňoví bratranci a sesternice patrili k stúpencom evanjelickej viery augsburského vyznania, čo vkladalo nádej do väššej akceptácie evanjelikov v správe. Očakávania sa prejavili aj vo výsledku reštaurácie, ked’ $50 \%$ postov obsadili evanjelici. ${ }^{18}$

Pri zvolení nemal Žigmund Görgey na vytvorenie pevnejšieho nepotizmu priaznivé podmienky. $\mathrm{V}$ rámci svojho rodu nepatril $\mathrm{k}$ najbohatším príslušníkom v dôsledku početnosti mužských príbuzných Ladislavovej vetvy Krištofovej línie hrhovskej hlavnej rodovej línie. Žigmundove štyri deti boli v čase reštaurácie zatial' slobodné, čo spôsobilo, že sa nemohol opriet' medzi podriadenými o najbližšiu rodinu. Ďalšou nevýhodou bolo, že ani jeho otec a starý otec v predošlom období nikdy nezastávali post riadneho podžupana, čím by iba znovu aktivoval už existujúcu siet' kontaktov. Ked’že oproti posledným vol'bám v roku 1720 sa zvýšil počet stoličných úradov o jeden post, Žigmund dosiahol 40 \% podiel „rodinných“ úradníkov. Priaznivému výsledku vd’ačil len početnosti členov rodu Görgey a ich sobášom, ktoré sa však systematicky neuzatvárali za účelom udržania si vplyvu v stoličnej administratíve.

Zastupujúcim podžupanom v roku 1725 nad’alej ostal bratranec Žigmunda Görgeya Štefan Görgey. Za riadneho notára zvolili klienta rodu Csáky Adama Almássyho, ktorého manželka bola neterou Zuzany Berzeviczyovej, pričom

Szinyei, tabul'ka II.

17 MV SR, Štátny archív v Prešove, f. Šarišská župa, i. č. 31 KP z rokov 1725 - 1726, pag. 224.

18 MV SR, SAL, f. SŽ, i. č. 71, KP z rokov $1725-1726$, k. 25, pag. 108-111; f. ZCM, i. č. 1, MRKF Abrahámovce, k. 1, pag. 635; i. č. 15, MRKF Bijacovce, k. 7, pag. 12; i. č. 25, MRKF Brutovce, k. 9, pag. 133; i. č. 251, MEF Kežmarok, k. 99, pag. 46; i. č. 619, MRKF Slovenská Ves, k. 231, pag. 183; i. č. 829, MRKF Spišský Hrhov, k. 319, pag. 86; i. č. 920, MEF Toporec, k. 352, pag. 122; SZLUHA, ref. 4, s. 77, 99, 306, 322. 
Zuzana bola druhostupňovou sesternicou Žigmundovho svokra. Z ostatných funkcií sa čiastočne podarilo dostat' pod kontrolu iba lokálne posty. Za zastupujúcich slúžnych v prvom okrese určili d’alšieho Žigmundovho bratranca Ladislava Görgeya a Alexandra Mattyasovszkého, ktorého svokra bola Žigmundovou sesternicou. Povinnosti riadneho slúžneho v druhom okrese prevzal syn Žigmundovej sesternice Peter Faigel a riadneho slúžneho v tret’om okrese iný Žigmundov bratranec Baltazár Görgey.

I ked' čast' podriadených Žigmunda Görgeya patrila medzi blízku pokrvnú rodinu, nepodarilo sa založit' úradnícku dynastiu. Žigmundov syn sa len okrajovo zúčastnil na administratíve Spišskej stolice a ním zároveň vymrela aj priama Žigmundova mužská línia. Okrem toho, prevziat' podžupanský post sa nepokúsili ani Žigmundovi bratranci. ${ }^{19}$

\section{Obdobie riadneho podžupana Štefana Máriássyho (1731 - 1754)}

Žigmund Görgey zomrel niekedy začiatkom septembra 1731 a krátko po jeho skone sa 11. septembra 1731 konali pod predsedníctvom hlavného župana Žigmunda Csákyho vol'by. Urobil tak napriek tomu, že v prípade úmrtí dvoch predošlých riadnych podžupanov vol'by nezvolal okamžite. Uvedená skutočnost' zrejme súvisela s obnovením Královskej miestodržitel'skej rady, ktorá zbierala údaje o zvolených úradníkoch zo všetkých uhorských stolíc a spolu s prijatými snemovými zákonmi nabádala županov, aby sa reštaurácie pravidelne opakovali každé dva či tri roky. ${ }^{20}$

Zo septembrových volieb vyšiel ako vít’az Štefan Máriássy. Ked’že pochádzal zo starobylého spišského rodu, mal dobré predpoklady pre vybudovanie nepotizmu. Navyše, jeho starý otec Žigmund Máriássy v rokoch 1650 - 1667 tiež zastával post podžupana. Na druhej strane sa však od poslednej tretiny 17. storočia s pribúdajúcim počtom Žigmundových príbuzných a potomkov prepadol majetkový status, a tým aj význam tejto línie rodu. Uvedená skutočnost' sa odrazila v tom, že Štefan v predošlom období zastával iba v rokoch $1713-1725$ post riadneho slúžneho tretieho okresu. Napriek svojmu pôvodu Štefan nedosiahol na vyššiu pozíciu. Príčina by sa zrejme mohla hladat'v tom, že v prvej tretine 18. storočia sa Štefan ešte stále hlásil ako všetci jeho príbuzní k evanjelickej viere augsburského vyznania. $Z$ prameňov sa nepodarilo doložit', kedy konvertoval na rímsko-katolícku vieru, ale $\mathrm{k}$ zmene náboženstva prikročil asi v rokoch

19 MV SR, SAL, f. ZCM, i. č. 15, MRKF Bijacovce, k. 7, pag. 12; SZLUHA, ref. 4, s. 77, 112-114, 264, 302; SZLUHA, ref. 8, Berzeviczy, Berzeviczei és Kakaslomniczi nemes és †báró, tabul'ka II.

20 MV SR, SAL, f. SŽ, i. č. 77, KP z rokov 1731 - 1732, k. 28, pag. 6-8; Articuli diaetales anni M. DCC. XXIII. Tyrnavia: Typis Academicis Societatis Jesu, 1740, s. 27, 28. 
1725 - 1731. S jeho konverziou sa zrejme spájala snaha o postupné znižovanie počtu evanjelikov v správe až na nula percent. ${ }^{21}$

Štefan Máriássy v predošlom období azda nepočítal s tým, že by ho niekedy zvolili za riadneho podžupana, a preto ani pred svojím zvolením systematicky nebudoval rodinnú siet'. V prípade svojich detí mohol pred reštauráciou zatial' ovplyvnit' len sobáš svojej najstaršej dcéry Magdy Máriássyovej, ked’že ostatné deti ešte nedosiahli potrebný vek na vydaj alebo boli len malými det'mi. Z hl'adiska posilnenia verejného Štefanovho vplyvu sa určujúcim stalo Magdine manželstvo s Gašparom Jancsóom. Gašparov otec Pavol Jancsó totiž ako právny splnomocnenec, a teda klient Csákyovcov, prišiel na Spiš začiatkom 18. storočia. Vd'aka tomu v rokoch 1711 - 1730 zastával post výbercu daní na hradnom panstve Spiš v rukách Csákyovcov a v rokoch 1725 - 1730 vykonával zároveň aj funkciu domáceho pokladníka. Pavol pôsobil aj ako právny splnomocnenec Csákyovcov. Po Pavlovej smrti niekedy v máji 1730 úrad výbercu daní na panstve v podstate zdedil jeho syn Gašpar Jancsó. ${ }^{22}$

Vd’aka relatívnej nepripravenosti Štefana Máriássyho na zvolenie za riadneho podžupana $\mathrm{v}$ septembrových vol'bách 1731 získal nízky podiel „rodinných“ úradníkov, iba $22,22 \%$. Z centrálnych úradov sa Štefanovi podarilo kontrolovat' jedine post domáceho pokladníka a zároveň výbercu daní na panstve Spiš, kde stavy potvrdili jeho zat’a Gašpara Jancsóa. Z lokálnych postov sa zastupujúcim slúžnym v tret’om okrese stal Gašparov brat František Jancsó a prísažným a zároveň výbercom daní v prvom okrese Pavol Kiss, ktorého manželka bola podžupanovou neterou. K okruhu „cirkevných“ úradníkov sa zarad’oval prísažný a výberca daní $\mathrm{v}$ druhom okrese Mikuláš Ujfalussy, pričom krstnou mamou jeho dcéry bola podžupanova manželka. ${ }^{23}$ Nižšie dosiahnuté číslo súviselo aj so zachovaním vyššieho podielu evanjelikov v správe, ked' z devätnástich úradov získali šest', čo predstavovalo $31,58 \%{ }^{24}$

21 MV SR, SAL, f. SŽ, i. č. 34, KP z rokov 1650 - 1661, k. 9, pag. 2; i. č. 36, KP z rokov $1665-1668$, k. 10 , pag. 165 ; i. č. $64, \mathrm{KP}$ z rokov $1713-1715$, k. 23 , pag. 5 ; i. č. $71, \mathrm{KP}$ z rokov $1725-1726$, k. 25, pag. 110; f. ZCM, i. č. 339, MRKF Levoča, k. 129, pag. 113; SZLUHA, ref. 4, s. 238, 239.

22 MV SR, SAL, f. SŽ, i. č. 63, KP z rokov $1711-1713$, k. 22, pag. 29; i. č. 67, KP z rokov $1720-1721$, k. 24 , pag. 30 ; i. č. 71 , KP z rokov $1725-1726$, k. 25 , pag. 110 ; i. č. 75 , KP z rokov 1729 - 1730, k. 28, pag. 273; SZLUHA, ref. 4, s. 160, 239, 246, 247.

23 MV SR, SAL, f. ZCM, i. č. 841, MRKF Spišský Hrušov, k. 322, pag. 93; SZLUHA, ref. 4, s. $160,239,246$.

24 MV SR, SAL, f. ZCM, i. č. 15, MRKF Bijacovce, k. 7, pag. 12; i. č. 144, MRKF Huncovce, k. 60 , pag. 19; i. č. 170, MRKF Chrast' nad Hornádom, k. 71, pag. 160; i. č. 340, MRKF Levoča, k. 129, pag. 28; i. č. 618, MRKF Slovenská Ves, k. 231, pag. 130; i. č. 619, MRKF Slovenská Ves, k. 231, pag. 183; i. č. 707, MRKF Spišská Kapitula, k. 269, pag. 368; i. č. 841, MRKF Spišský Hrušov, k. 322, pag. 83, 120, 133; i. č. 920, MEF Toporec, k. 352, pag. 122; SZLUHA, ref. 4, s. 62, 99, 160, 164, 306. 
V nasledujúcich vol'bách 18. februára 1739 sa síce situácia v prospech Štefana Máriássyho čiastočne zlepšila, ked' dosiahol 26,66 \% podiel „rodinných“ úradníkov, ale na druhej strane to spôsobila skutočnost', že sa počet volených úradov oproti roku 1731 znížil o tri miesta na šestnást' postov. Z centrálnych úradov sa domácim pokladníkom stal Pavol Kiss a post výbercu daní na panstve Spiš si udržal František Jancsó. Za zastupujúceho slúžneho, prísažného a výbercu daní v podkarpatskom dištrikte prvého okresu zvolili brata Pavla Kissa Juraja Kissa a rovnakú funkciu, ale v prvom dištrikte druhého okresu nadobudol Michal Vitális, ktorého švagrinou bola podžupanova neter. ${ }^{25}$ Priaznivejšie postavenie Máriássy docielil napriek tomu, že evanjelici mali v týchto vol’bách so šiestimi šl'achticmi 37,5 \% podiel. ${ }^{26}$ Ako problém volieb sa ukázalo, že Gašpar Jancsó v roku 1734 predčasne zomrel ako bezdetný a podžupan nemohol do budúcnosti počítat' so svojimi vnukmi a vnučkami z Jancsóovskej rodiny ako potencionálnymi pokračovatel'mi dynastie.

Obrat vo vytvorení nepotistickej siete Štefana Máriássyho znamenala asi v roku 1741 premyslená svadba jeho iba dvanástročnej dcéry Júlie Máriássyovej s dvadsat'ročným podnotárom Ladislavom Mattyasovszkým. Ženích síce pochádzal z podstatne chudobnejšieho rodu, ale priniesol vel'kú devízu v podobe početného príbuzenstva so silnými rodinnými väzbami na niekol'ko rodov. Z hl'adiska Máriássyho nepotizmu sa ako najdôležitejšie prejavili sobášne zväzky Mattyasovszkých s Görgeyovcami, s ktorými najbližšie Máriássyho pokrvné príbuzenstvo $\mathrm{v}$ minulosti neuzavieralo žiadne manželstvá. Podstatný faktor predstavovalo, že predošlý riadny podžupan Žigmund Görgey bol bratrancom detí Anny Mattyasovszkej, ktorá bola tetou Ladislava Mattyasovszkého. Ďalším pozitívom bolo, že starší Ladislavov brat Alexander Mattyasovszky bol priamo krstným synom Žigmunda Görgeya a mladší Ladislavov brat Tomáš Görgey mal za krstnú matku vdovu po Žigmundovi Görgeyovi Helenu Berzeviczyovú. Máriássy chcel svadbou svojej dcéry demonštrovat' kontinuitu s obdobím svojho predchodcu. ${ }^{27}$

Dva roky po spomínanej svadbe sa 1 . februára 1743 konali vol'by, v ktorých sa zastúpenie evanjelikov výrazne znížilo oproti predošlej reštaurácii na $10,53 \%{ }^{28} \mathrm{Aj}$ vd’aka tomu sa v správe mohli uplatnit' katolíci, a teda príbuzenstvo

25 MV SR, SAL, f. SŽ, i. č. 85, KP z roku 1739, k. 32, pag. 21-24; f. ZCM, i. č. 144, MRK Huncovce, k. 60, pag. 19, 35; SZLUHA, ref. 4, s. 239, 424.

26 MV SR, SAL, f. ZCM, i. č. 144, MRKF Huncovce, k. 160, pag. 35; i. č. 340, MRKF Levoča, k. 283; i. č. 409, MRKF L'ubica, k. 154, pag. 234; i. č. 829, MRKF Spišský Hrhov, k. 319, pag. 90; SZLUHA, ref. 4, s. 103, 303, 424.

27 MV SR, SAL, f. ZCM, i. č. 617, MRKF Slovenská Ves, k. 231, pag. 106; i. č. 618, MRKF Slovenská Ves, k. 231, pag. 38; SZLUHA, ref. 4, s. 112, 113, 246, 264, 265.

28 MV SR, SAL, f. SŽ, i. č. 89, KP z roku 1743, k. 34, pag. 2-5; f. ZCM, i. č. 707, MRKF Spišská Kapitula, k. 269, pag. 383; i. č. 1021, MRKF Vyšný Slavkov, k. 393, pag. 228; SZLUHA, 
Štefana Máriássyho. Podiel jeho „rodinných“ úradníkov sa viac ako zdvojnásobil na $61,11 \%$. Zastupujúcim podžupanom sa stal Peter Faigel, ktorého matka bola sesternicou Žigmunda Görgeya a zároveň neterou tety Ladislava Mattyasovszkého. Do Máriássyho područia sa z centrálnych úradov dostal notariát, kde za riadneho notára zvolili právneho splnomocnenca grófa Mikuláša Csákyho Andreja Daxnera, ktorého svokra bola tetou Anny Péchyovej a tá bola švagrinou Alexandra Mattyasovszkého. Za podnotára určili neskoršieho liptovského riadneho podžupana Antona Okolicsányiho, ktorého neter bola švagrinou Júlie Máriássyovej. Zároveň však Okolicsányi ako pomocnú silu získal Štefanovho syna Františka Xavera Máriássyho. Financie na poste vojenského a domáceho pokladníka riadil švagor Alexandra Mattyasovszkého Ezechiel Görgey. Ked’že Görgey v čase zvolenia velil stoličnému bandériu ako kapitán, na výpomoc mu priradili Alexandra Mattyasovszkého, ktorého zároveň zvolili za riadneho slúžneho v prvom okrese. ${ }^{29}$

Na lokálnej úrovni v prvom okrese okrem Alexandra Mattyasovszkého za riadneho prísažného a výbercu daní v podkarpatskom dištrikte zvolili Jána Vitálisa, ktorého žena bola neterou Štefana Máriássyho, a do rovnomennej funkcie, ale v dunajeckom dištrikte, Samuela Királyho, ktorého predpokladaná matka bola neterou tety Ladislava Mattyasovszkého. V druhom okrese si za riadneho slúžneho určili Ladislava Mattyasovzského a za zastupujúceho slúžneho Imricha Budaházyho, ktorého svokra bola švagrinou tety Ladislava Mattyasovszkého. Riadnym slúžnym v tret’om okrese sa stal niekdajší švagor Magdy Máriássyovej František Jancsó. Napokon za pokladníka na panstve Spiš Csákyovci priamo menovali Ladislava Gundelfingera, ktorého svokra bola tret'ostupňovou sesternicou Magdinho švagra. ${ }^{30}$

Vd’aka sobášom Petra Horanszkého so sesternicou Ladislava i Alexandra Mattyasovszkého Máriou Görgeyovou a druhému vydaju Magdy Máriássyovej za Alexandra Berzeviczyho niekedy medzi rokmi 1743 - 1747 sa nasledujúce vol'by 17. januára 1747 stali úspešnejšími. ${ }^{31}$ Podiel evanjelikov ${ }^{32}$ sa znížil s jedným šlachticom na 5,55 \% a podiel „rodinných“ úradníkov Štefana Máriássyho

ref. 4, s. 77, 112, 131, 424; SZLUHA, ref. 7, s. 442.

29 SZLUHA, ref. 4, s. 58, 77, 102, 103, 112, 113, 246, 264, 265; SZLUHA, ref. 7, s. 442; SZLUHA, ref. 8, Bornemisza, Kálnoi és Ádámföldi; Péchy, Péchújfalusi nemes és †gróf, tabul'ka X.

30 SZLUHA, ref. 4, s. 37, 112, 113, 124, 125, 131, 160, 238, 239, 246, 264, 265, 424.

31 MV SR, SAL, f. SŽ, i. č. 92, KP z rokov $1746-1747$, k. 35, pag. 411-414; SZLUHA, ref. 4, s. 112, 246, 264, 265; SZLUHA, ref. 7, s. 214.

32 MV SR, SAL, f. ZCM, i. č. 15, MRKF Bijacovce, k. 7, pag. 12; i. č. 170, MRKF Chrast' nad Hornádom, k. 71, pag. 191; i. č. 829, MRKF Spišský Hrhov, k. 319, pag. 8; SZLUHA, ref. 7, s. 125, 214; SZLUHA, ref. 8, Berzeviczy, Berzeviczei és Kakaslomniczi nemes és †báró, tabul'ka IX. 
sa vyšplhal na úroveň 76,47 \%. Na centrálnej úrovni zostal zastupujúcim podžupanom Ezechiel Görgey, za riadneho notára zvolili Františka Jancsóa a za podnotára Františka Xavera Máriássyho. Na poste pokladníka oboch kás sa objavil nový podžupanov zat' Alexander Berzeviczy.

Na lokálnej úrovni v prvom okrese sa zastupujúcim slúžnym stal Ján Vitális a výbercom daní v podkarpatskom dištrikte Peter Horanszky. V druhom okrese došlo k jeho celkovému ovládnutiu príslušníkmi nepotistickej siete. Na poste riadneho slúžneho potvrdili Ladislava Mattyasovszkého, za zastupujúceho slúžneho vybrali Žigmunda Görgeya, ktorého matka bola sestrou novej svokry Magdy Máriássyovej. Za výbercu daní v dištrikte Štiavnik určili Jána HorváthaKissevitha, ktorého predpokladaná švagriná bola švagrinou Zuzany Berzeviczyovej a tá bola švagrinou Magdy Máriássyovej, a v dištrikte Letanovce brata Petra Horanszkého, Jozefa Horanszkého. V tret'om okrese sa podarilo obsadit' iba post výbercu daní pravdepodobne bratom Jána Horvátha-Kissevitha Jozefom Horváthom-Kissevithom. Pokladníkom panstva Spiš z rozhodnutia hlavného župana zostal Ladislav Gundelfinger. Župan zároveň aj priamo menoval fiškála Juraja Horvátha-Kissevitha, ktorý bol pravdepodobne bratom Jána a Jozefa Horváthovcov-Kissevithovcov. ${ }^{33}$

Vrchol moci Štefana Máriássyho predstavovali vol'by 30. júna 1750, ked' evanjelici nezískali žiadny post $\mathrm{v}$ správe Spišskej stolice ${ }^{34}$ a riadny podžupan dosiahol až 94,11 \% podiel „rodinných“ úradníkov. K vynikajúcemu volebnému výsledku napomohlo, že sa Ladislav Ujfalussy v roku 1746 oženil s Janou Görgeyovou, František Jancsó v roku 1748 s Júliou Görgeyovou a niekedy v rovnakom čase sa sestra Ladislava Mattyasovszkého vydala za Mikuláša Almássyho.

Vd’aka tomu centrálne úrady obsadil zastupujúci podžupan Andrej Daxner, riadny notár František Jancsó, podnotár Mikuláš Almássy, pokladník oboch kás František Xaver Máriássy a fiškál Juraj Horváth-Kissevith. V prvom okrese sa riadnym slúžnym stal Ján Vitális, zastupujúcim slúžnym syn Petra Faigela Žigmund Faigel, výbercom daní v dunajeckom dištrikte Ladislav Ujfalussy, ktorého svokor bol synovcom tety Ladislava Mattyasovszkého, a výbercom daní v podkarpatskom dištrikte brat Jána Vitálisa Štefan Vitális. V druhom okrese posty prevzali riadny slúžny Alexander Görgey, ktorý bol bratrancom manželky Františka Jancsóa, zastupujúci slúžny Ján Horváth-Kissevith, výberca daní v dištrikte Štiavnik Peter Horanszky, výberca daní v dištrikte Letanovce Jozef Horanszky. V tret’om okrese pozície zaujali riadny slúžny Ján Görgey, ktorý bol bratrancom

33 SZLUHA, ref. 4, s. 113, 149, 394, 395; SZLUHA, ref. 7, s. 214; SZLUHA, ref. 8, Berzeviczy, Berzeviczei és Kakaslomniczi nemes és †báró, tabul'ka II, IX.

34 MV SR, SAL, f. SŽ, i. č. 96, KP z rokov 1750 - 1751, k. 38, pag. 48, 49; f. ZCM, i. č. 841, MRKF Spišský Hrušov, k. 322, pag. 83; SZLUHA, ref. 4, s. 77, 125, 424. 
manželky Františka Jancsóa a výberca daní Jozef Horváth-Kissevich. Pokladníkom panstva Spiš zostal Ladislav Gundelfinger. ${ }^{35}$

Štefan Máriássy vd’aka premyslenej sobášnej stratégii založil úradnícku dynastiu, ked’že mal svojho nasledovníka v podobe vlastného syna Františka Xavera Márássyho. Zároveň si zabezpečil, aby sa aj pri vol'be riadneho podžupana $\mathrm{v}$ prípade neúspechu jeho syna $\mathrm{k}$ riadeniu stolice dostali niektorí z najbližších príbuzných. Úspešnost' sa pretavila i v skutočnosti, že sa Štefan stal vôbec najdlhšie pôsobiacim riadnym spišským podžupanom 18 . storočia.

\section{Obdobie riadneho podžupana Ezechiela Görgeya (1754 - 1762)}

Štefan Máriássy zomrel 10. apríla 1754 a vtedajší hlavný župan Mikuláš Csáky nezvolal vol'by okamžite a ani nikoho dočasne nevymenoval na jeho miesto. Uvedená skutočnost' zrejme súvisela s tým, že zastupujúcim podžupanom bol v čase Máriássyho úmrtia Andrej Daxner, ktorý dlhodobo pôsobil ako prefekt panstiev kaločského arcibiskupa a kardinála Imricha Csákyho. Daxner nepochádzal zo Spiša, a preto mu Csákyovci v roku 1743 dali do zálohu majetky v Spišskom Hrušove. Mikuláš Csáky chcel zrejme nepriamo spišskej šlachte ukázat', že si želá za nového riadneho podžupana niekdajšieho prefekta svojho zosnulého brata. Mikuláš Csáky nakoniec zvolal vol’by na 10. októbra 1754, kde sa však nechal zastúpit' svojím synovcom Antonom Csákym. Stavy však nezvolili za riadneho podžupana Daxnera, ale príslušníka starobylého domáceho rodu Ezechiela Görgeya. ${ }^{36}$

Pri vol'be nového riadneho podžupana zrejme zohralo istú úlohu aj náboženské zázemie oboch rodov. Daxnerovci sa hlásili iba ku katolíckej viere, ale príbuzní Ezechiela Görgeya praktikovali aj evanjelickú vieru. Istým prejavom uvol’nenia oproti poslednej reštaurácii za Štefana Máriássyho sa stalo, že medzi úradníkov zvolili aj dvoch evanjelikov, čo predstavovalo $11,11 \%{ }^{37} \mathrm{Z}$ hl'adiska nepotizmu sa dosiahli tiež priaznivé výsledky v podobe $76,47 \%$ zastúpenia

35 SZLUHA, ref. 4, s. 112, 113, 125, 160, 264, 265, 408, 424. Jedine zastupujúceho slúžneho tretieho okresu Ignáca Vitkoczyho sa nepodarilo zaradit' do podžupanovej siete, pretože k rodu neboli k dispozícii genealogické tabul'ky a ani matričný výskum nič nepotvrdil. Na druhej strane nie je ale vylúčené, že aj Ignác Vitkóczy patril k „,rodinným“ úradníkom.

36 MV SR, SAL, f. SŽ, i. č. $100, \mathrm{KP}$ z rokov $1754-1755$, k. 40, pag. 35-38; f. ZCM, i. č. 170, MRKF Chrast' nad Hornádom, k. 71, pag. 160; JANURA - HAVIAROVÁ, ref. 4, s. 135; SZLUHA, ref. 4, s. 48, 49.

37 MV SR, SAL, f. ZCM, i. č. 15, MRKF Bijacovce, k. 7, pag. 12; i. č. 25, MRKF Brutovce, k. 9, pag. 133, 137; i. č. 409, MRKF L’ubica, k. 154, pag. 276; i. č. 366, MEF Levoča, k. 138, pag. 264; i. č. 618, MRKF Slovenská Ves, k. 231, pag. 117; i. č. 841, MRKF Spišský Hrušov, k. 322, pag. 83, 133, 163; i. č. 1021, MRKF Vyšný Slavkov, k. 393, pag. 228; SZLUHA, ref. 4, s. 77, 103, 125, 424; SZLUHA, ref. 7, s. 214. 
„rodinnými“ úradníkmi. Žičlivé obsadenie stoličného magistrátu vychádzalo aj z toho, že Ezechiel bol v rokoch 1747 - 1750 zastupujúcim podžupanom a dalo sa predpokladat', že sa raz stane aj riadnym podžupanom. ${ }^{38}$

Z hl'adiska budovania nepotizmu sa Ezechiel Görgey mohol opriet' aj o príbuzenstvo, ktoré si vytvoril jeho starý otec Baltazár Görgey, podžupan v rokoch 1684 - 1698. V 18. storočí v rokoch 1725 - 1731 pozíciu riadneho podžupana obsadil Žigmund Görgey, ktorý bol bratrancom Ezechielovej matky. Ked’že obaja Görgeyovskí podžupani systematicky nebudovali siet' rodinkárstva, pozitívny výsledok z roku 1754 vyplynul len zo sobášov početného Ezechielovho príbuzenstva s viacerými rodmi. Samotný Ezechiel si cielene ešte pred zvolením do úradu vytvoril iba „,cirkevných“ úradníkov medzi v administratíve angažovanými rodmi Horváth-Kissevith, Theőke a Vitkóczy. ${ }^{39}$

V októbri 1754 sa Ezechielovi Görgeyovi podarilo na centrálnej úrovni dosiahnut' nasledujúce posty: zastupujúcim podžupanom ostal Andrej Daxner, ktorého svokra bola sesternicou Ezechielovej svokry. Ako riadneho notára potvrdili Františka Jancsóa, ktorého bývalá švagriná bola švagrinou Ladislava Mattyasovszkého a ten bol bratom Ezechielovho švagra. Na stoličke podnotára potvrdili Mikuláša Almássyho, ktorý bol švagrom Alexandra Mattyasovszkého a ten bol Ezechielovým švagrom. Fiškálsky úrad aj po reštaurácii nad’alej vykonával Juraj Horváth-Kissevith, pričom synovci jeho predpokladanej švagrinej mali za krstného otca Ezechielovho brata Vavrinca Görgeya. ${ }^{40}$

Na lokálnej úrovni v prvom okrese zvolili za riadneho slúžneho Jána Vitálisa, ktorého stará matka bola tetou švagra Ezechiela Görgeya, a ako zastupujúceho slúžneho potvrdili Žigmunda Faigela, pričom jeho svokor bol švagrom tety Alexandra Mattyasovszkého. V druhom okrese zostali pôsobit’ riadny slúžny Alexander Görgey, ktorého sesternica bola manželkou Františka Jancsóa, a zastupujúci slúžny Ján Horváth-Kissevith, brat Juraja Horvátha-Kissevitha. V tret’om okrese sa novým riadnym slúžnym stal Ignác Vitkóczy a zastupujúcim slúžnym Krištof Theőke, pričom deti oboch úradníkov mali za krstného otca Ezechiela. Spomedzi výbercov daní schválili v podkarpatskom dištrikte Ladislava Ujfalussyho, ktorého svokra bola švagrinou Evy Péchyovej a tá bola sesternicou Ezechielovho svokra; v letanovskom dištrikte Jozefa Horanszkého, ktorého švagriná bola dcérou Anny Mattyasovszkej, ktorá bola tetou Ezechielovho švagra;

38 MV SR, SAL, f. SŽ, i. č. 92, KP rokov 1746 - 1747, k. 35, pag. 411; i. č. 96, KP z rokov 1750 - 1751, k. 38, pag. 48.

39 MV SR, SAL, f. SŽ, i. č. 43, KP z rokov $1684-1686$, k. 12, pag. 9; i. č. 52, KP z rokov $1698-1699$, k. 15, pag. 6; SZLUHA, ref. 4, s. 102, 103, 112, 113.

40 MV SR, SAL, f. ZCM, i. č. 827, MRKF Spišský Hrhov, k. 319, pag. 51; SZLUHA, ref. 4, s. 52, 103, 149, 160, 246, 264, 265; SZLUHA, ref. 8, Bornemisza, Kálnoi és Ádámföldi; Péchy, Péchújfalusi nemes és †gróf, tabul'ka X. 
a v tret'om okrese Jozefa Horvátha-Kissevitha, pričom synovci jeho manželky boli krstnými det'mi Ezechielovho brata Vavrinca Görgeya. ${ }^{41}$

Ezechiel Görgey sa po zvolení za riadneho podžupana snažil upevnit' hlavne prepojenie na zastupujúceho podžupana Františka Jancsóa. Preto sa po reštaurácii v nasledujúcom roku 4. mája 1755 Júlia Görgeyová, druhostupňová sesternica manželky Františka Jancsóa, stala druhou manželkou Alexandra Mattyasovszkého, ktorého prvá manželka bola sestrou úradujúceho riadneho podžupana. Upevnená väzba na Jancsóa sa vyplatila pri d’alších vol'bách 31. júla 1759, ked’ síce najprv zvolili Františka Xavera Máriássyho, syna predošlého riadneho podžupana, ale ten sa vzdal postu v prospech Jancsóa. ${ }^{42}$

V júlových vol'bách 1759 už zvolili len jedného evanjelického úradníka oproti predošlej reštaurácii, čo predstavovalo $5,26 \%$ podiel.${ }^{43} \mathrm{Na}$ druhej strane sa zvýšením počtu katolíkov podiel „rodinných“ úradníkov zvýšil na úroveň 83,33 \%. Z centrálnych úradov okrem spomenutého zastupujúceho podžupana zostal nad’alej pod kontrolou notariát. Hlavný župan Ján Nepomuk Csáky za riadneho notára priamo vymenoval Františka Podhorányiho, ktorý bol pravdepodobne bratom alebo bratrancom Gabriela Podhorányiho, pričom svokrom Gabrielovej dcéry bol Alexander Mattyasovszky. Csáky určil aj dvoch podnotárov: Gašpara Horvátha-Kissevitha, ktorý bol asi bratom alebo bratrancom spomínaného Jozefa Horvátha-Kissevitha, a Rikolfa Berzeviczyho, ktorého bratranec bol druhým manželom Magdy Máriássyovej, niekdajšej švagrinej Františka Jancsóa. Oproti predošlej reštaurácii Ezechiel nadobudol aj post všeobecného pokladníka, kam zvolili Gabriela Podhorányiho. Fiškálom nad’alej zostal Juraj Horváth-Kissevith. $^{44}$

Na miestnej úrovni v prvom okrese vytrvali riadny slúžny Ján Vitális a výberca daní v podkarpatskom dištrikte Ladislav Ujfalussy, ale za nového zastupujúceho slúžneho zvolili Adama Svábyho, ktorého matka bola vdovou po strýkovi Alexandra Mattyasovszkého. V druhom okrese si svoje posty udržal riadny slúžny Alexander Görgey a zastupujúci slúžny Ján Horváth-Kissevith, ale v levočskom dištrikte nominovali za výbercu daní Imricha Doloviczénya, ktorého manželka bola pravdepodobne sestrou alebo sesternicou Jozefa Horanszkého. V tret’om

41 MV SR, SAL, f. ZCM, i. č. 827, MRKF Spišský Hrhov, k. 319, pag. 66; i. č. 1021, MRKF Vyšný Slavkov, k. 393, pag. 60, 64; SZLUHA, ref. 4, s. 77, 102, 103, 112, 113, 125, 160, 264 , 265, 408, 424; SZLUHA, ref. 8, Péchy, Péchújfalusi nemes és †gróf, tabul'ka X, XIII, XIX.

42 MV SR, SAL, f. SŽ, i. č. 105, KP z roku 1759, k. 43, pag. 192-194; SZLUHA, ref. 4, s. 103, 125, 160, 264.

43 MV SR, SAL, f. ZCM, i. č. 849, MRKF Spišský Štvrtok, k. 326, pag. 268; SZLUHA, ref. 4 , s. 159. SZLUHA, ref. 7, s. 548, 549. SZLUHA, ref. 8, Berzeviczy, Berzeviczei és Kakaslomniczi nemes és †báró, tabul'ka IX.

44 SZLUHA, ref. 4, 160, 246, 264, 265; SZLUHA, ref. 7, s. 548; SZLUHA, ref. 8, Berzeviczy, Berzeviczei és Kakaslomniczi nemes és †báró, tabul'ka IX. 
okrese zostal riadnym slúžnym Ignác Vitkóczy a zastupujúcim slúžnym sa stal niekdajší výberca daní tretieho okresu Jozef Horváth-Kissevith. Hlavný župan na post pokladníka panstva dosadil niekdajšieho výbercu daní v letanovskom dištrikte Jozefa Horanszkého. ${ }^{45}$

\section{Obdobie Františka Jancsóa (1762 - 1776)}

Ezechiel Görgey síce zomrel 18. februára 1762, ale ani hlavný župan Ján Nepomuk Csáky okamžite nezvolal vol'by a počkal až do 12. augusta 1762. Kompetencie riadneho podžupana dovtedy vykonával zastupujúci podžupan František Jancsó, čím sa opät' po Andrejovi Daxnerovi k riadeniu stolice dostal príslušník Csákyovského klientelistického rodu. Csáky predpokladal, že sa Jancsó v priebehu pol roka natol'ko osvedčí, že ho v najbližšej reštaurácii stavy automaticky akceptujú. Augustové vol'by nakoniec priniesli Františkovi Jancsóovi na rozdiel od rovnako klientelistického Andreja Daxnera postup na očakávanú stoličku riadneho podžupana. ${ }^{46}$

Pri zisku najvyššieho stoličného voleného postu v prípade Františka Jancsóa zohral úlohu podstatný rozdiel oproti Andrejovi Daxnerovi. V čase volieb bol totiž Jancsó napriek tomu, že jeho otec prišiel začiatkom 18. storočia na Spiš zo Sedmohradska v sprievode Csákyovcov, pevne etablovaný a rešpektovaný šlachtic prostredníctvom príbuzenských väzieb s členmi rodu Görgeyovcov, Máriássyovcov a Mattyasovszkých. Ďalší dôležitý faktor v prospech Jancsóa predstavoval, že syn Štefana Máriássyho František Xaver Máriássy nekandidoval na riadneho podžupana. V čase smrti Ezechiela Görgeya sa Máriássy angažoval v správe Gemerskej stolice a nariadenia panovníkov zakazovali zastávanie platených stoličných úradov vo viacerých stoliciach súbežne. ${ }^{47}$

František Jancsó nemal sám vel'ké možnosti aktívne ovplyvnit' vytvorenie nepotistickej siete, ked’že pochádzal z úzkeho rodinného kruhu. Preto sa opieral hlavne o rozvetvené príbuzenstvo spomínaných rodov. Čiastočne si aktívne získal „cirkevných“ úradníkov prostredníctvom rodu Horváth-Kissevith. Pri augustových vol'bách v roku 1762 zvolili len jedného evanjelika, čo predstavovalo $5,55 \%$ a aj vd’aka tomu podiel „rodinných“ úradníkov dosiahol 83,33\%.48

45 MV SR, SAL, f. ZCM, i. č. 849, MRKF Spišský Štvrtok, k. 326, pag. 268; SZLUHA, ref. 4, s. $264,265,354$.

46 MV SR, SAL, f. SŽ, i. č. 108 , KP z roku 1762, k. 44, pag. 316-318; f. ZCM, i. č. 829, MRKF Spišský Hrhov, k. 319, pag. 91.

47 MV SR, SAL, f. ZCM, i. č. 170, MRKF Chrast' nad Hornádom, k. 71, pag. 39, 42, 43, 46, 49.

48 MV SR, SAL, f. ZCM, i. č. 15, MRKF Bijacovce, k. 7, pag. 12; i. č. 25, MRKF Brutovce, k. 9, pag. 133, 137; i. č. 170, MRKF Chrast' nad Hornádom, k. 71, pag. 191; i. č. 409, MRKF Lubica, k. 154, pag. 276; i. č. 620, MRKF Slovenská Ves, k. 231, pag 252, 285; i. č. 849, MRKF Spišský Štvrtok, k. 326, pag. 91, 117, 268; i. č. 850, MRKF Spišský Štvrtok, k. 326, pag. 21; i. č. 1021 MRKF Vyšný Slavkov, k. 393, pag. 228; SZLUHA, ref. 4, s. 131, 148, 149, 
Na centrálnej úrovni sa zastupujúcim podžupanom stal František Xaver Máriássy, ktorého sestra Magda Máriássyová bola kedysi manželkou nebohého brata Františka Jancsóa. Hlavný župan za riadneho notára priamo menoval Martina Dobaya, ktorého matka bola druhostupňovou sesternicou Františkovej manželky. Za podnotárov župan určil Magdinho synovca Mikuláša Mattyasovszkého a Rikolfa Berzeviczyho, ktorý bol bratrancom druhého manžela Magdy Máriássyovej. Na poste všeobecného pokladníka sa udržal Gabriel Podhorányi, ktorého strýko bol švagrom riadneho podžupana. Csáky priamo na post fiškála dosadil Gašpara Horvátha-Kissevitha, pričom pravdepodobne jeho synovci mali za krstného otca Jancsóa. ${ }^{49}$

Na miestnej úrovni sa Františkovi Jancsóovi podarilo v prvom okrese získat' riadneho slúžneho Mikuláša Almássyho, ktorého manželka bola švagrinou Júlie Máriássyovej a tá bola sestrou Magdy Máriássyovej. Zastupujúcim slúžnym sa stal Jozef Ribiczey, pričom pravdepodobne synovci jeho manželky boli Jancsóovými krstným det’mi. Za výbercu daní v podkarpatskom dištrikte zvolili Imricha Doloviczénya. Jeho manželka bola zrejme najbližšou pokrvnou rodinou Jozefa Horanszkého, ktorého švagriná bola sesternicou Žigmunda Görgeya, ktorý bol zase svokrom druhostupňovej sesternice Jancsóovej manželky. V druhom okrese vybrali nového riadneho slúžneho Jána Horvátha-Kissevitha, ktorý bol zrejme bratom alebo bratrancom Gašpara Horvátha-Kissevitha. Za výbercu daní $\mathrm{v}$ letanovskom dištrikte priamo menovali Adama Pavlikovicsa, ktorý bol pravdepodobne synovcom Jána Vitálisa, ktorého manželka bola sesternicou Magdy Máriássyovej; a v štiavnickom dištrikte Tomáša Doloviczénya, ktorého manželka Anna Horváthová-Kissevithová bola pravdepodobne najbližšou pokrvnou rodinou Jancsóových krstniat. V tret’om okrese potvrdili ako riadneho slúžneho Ignáca Vitkóczyho, ktorý bol otcom Jancsóových krstniat. Nový zastupujúci slúžny Ladislav Gundelfinger bol švagrom sestry Magdy Máriássyovej. Za výbercu daní panstva hradu Spiš Csáky určil Jozefa Horanszkého. ${ }^{50}$

Počas nasledujúcich volieb 4. augusta 1767 zostal iba jeden zvolený evanjelik, čo predstavovalo $5 \%$ a zachoval sa aj rovnaký počet pätnástich „,rodinných“ úradníkov, ale kvôli zvýšeniu počtu volených funkcií o jednu sa vd’aka tomu

159; SZLUHA, ref. 7, s. 214, 548, 549; SZLUHA, ref. 8, Berzeviczy, Berzeviczei és Kakaslomniczi nemes és †báró, tabul'ka IX, Dobay, Dobói, tabul'ka III.

49 SZLUHA, ref. 4, s. 124, 125, 148, 149, 160, 246, 264-266; SZLUHA, ref. 7, s. 548, 549; SZLUHA, ref. 8, Berzeviczy, Berzeviczei és Kakaslomniczi nemes és †báró, tabul'ka I; Dobay, Dobói, tabul'ka III.

50 MV SR, SAL, f. ZCM, i. č. 849, MRKF Spišský Štvrtok, k. 326, pag. 266, 268; i. č. 850 , MRKF Spišský Štvrtok, k. 326, pag. 21; i. č. 1021, MRKF Vyšný Slavkov, k. 393, pag. 62, 80; i. č. 1057, MRKF Žehra, k. 407, pag. 306; SZLUHA, ref. 4, s. 112, 113, 125, 131, 148, 149 , 160, 238, 239, 246, 247, 264, 265; SZLUHA, ref. 7, s. 214. 
výsledný podiel v prospech Františka Jancsóa znížil na 78,94 \%. ${ }^{51} \mathrm{Z}$ ústredných stoličných funkcií sa novým zastupujúcim podžupanom stal druhostupňový bratranec Jancsóovej manželky Ján Görgey. Na notariáte sa udržal riadny podžupan Martin Dobay a podnotár Mikuláš Mattyasovszky. Ako zastupujúceho podnotára a zároveň archivára hlavný župan Ján Nepomuk Csáky menoval Jána Bárdossyho, ktorého deti boli Jancsóovými krstňatami. Csáky pomohol Jancsóovi aj pri obsadení fiškalátu, pretože za riadneho fiškála určil Michala Kissóczyho, ktorého manželka bola neterou Michala Mattyasovszkého a ten bol strýkom Ladislava Mattyasovszkého, švagra nebohého Jancsóovho brata. Post zastupujúceho fiškála pridelil Jánovi Berzeviczymu, ktorého bratranec bol bratrancom Jána Vitálisa a ten mal za manželku sesternicu Magdy Máriássyovej. ${ }^{52}$

Na lokálnej úrovni v prvom okrese potvrdili riadneho slúžneho Mikuláša Almássyho a vyberača daní v podkarpatskom dištrikte Imricha Doleviczénya. Za zastupujúceho slúžneho zvolili Adama Svábyho, ktorého nevlastná sestra bola sesternicou Ladislava Mattyasovszkého. V druhom okrese si z predošlého obdobia zachovali svoje pozície výbercovia daní, v štiavnickom dištrikte Tomáš Doleviczény a v letanovskom dištrikte Adam Pavlikovics. Za zastupujúceho slúžneho si stavy vybrali Mateja Bobesta, ktorého nevlastná sestra bola sesternicou Žigmunda Görgeya a jeho manželka bola druhostupňovou sesternicou Jancsóovej manželky. V tret’om okrese došlo k výmene predošlých úradníkov. Novým riadnym slúžnym sa stal Ján Horváth-Kissevith, ktorého synovci boli Jancsóovými krstňatami a zastupujúcim slúžnym synovec Magdy Máriássyovej Pavol Máriássy. Na poste pokladníka panstva Spiš nad’alej zotrval Jozef Horanszky. ${ }^{53}$

Po vol'bách v roku 1767 sa František Jancsó vynasnažil upevnit' niektoré príbuzenské väzby, a preto sa 24. júla 1768 konala svadba Martina Dobaya s Klárou Péchyovou, ktorej bratranci a sesternice boli det’mi Jancsóovej netere Gertrúdy Podhorányiovej. Dňa 19. marca 1771 sa bratranec Magdy Máriássyovej Ignác Berzeviczy oženil s Jancsóovou dcérou Máriou Jancsóovou. Niekedy medzi rokmi 1767 - 1772 sa konala svadba Juraja Berzeviczyho so sestrou neskoršieho podnotára Michala Theőkeho Klárou Theőkeovou. Berzeviczyho otec bol

51 MV SR, SAL, f. SŽ, i. č. 113, KP z roku 1767, k. 47, pag. 414-416, f. ZCM, i. č. 1, MRKF Abrahámovce, k. 1, pag. 41, 79; i. č. 620, MRKF Slovenská Ves, k. 231, pag. 252; i. č. 410, MRKF Luubica, k. 154, pag. 185; i. č. 710, MRKF Spišská Kapitula, k. 270, pag. 332; i. č. 914, MRKF Toporec, k. 351, pag. 27; i. č. 1021, MRKF Vyšný Slavkov, k. 393, pag. 88. SZLUHA, ref. 4, s. 125, 246, 419; SZLUHA, ref. 8, Berzeviczy, Berzeviczei és Kakaslomniczi nemes és †báró, tabul'ka VI.

52 MV SR, SAL, f. ZCM, i. č. 1021, MRKF Vyšný Slavkov, k. 393, pag. 88; SZLUHA, ref. 4, s. 100, 125, 160, 238, 239, 246, 264, 265, 424; SZLUHA, ref. 8, Berzeviczy, Berzeviczei és Kakaslomniczi nemes és †báró, tabul'ka VI.

53 SZLUHA, ref. 4, s. 28, 112, 113, 124, 125, 148, 149, 246, 264, 265, 354. 
bratrancom Alexandra Berzeviczyho, ktorý bol svokrom Magdy Máriássyovej. Tesne pred d'alšími vol'bami sa 16. augusta 1772 konala svadba výbercu daní tretieho okresu Štefana Nemessányiho so Žofiou Detrichovou a ich svedkom sa stal práve riadny podžupan. ${ }^{54}$

Dňa 25 . augusta 1772 vo vol'bách už zvolili dvoch evanjelikov, teda $11,11 \%$, ale vd'aka zníženiu funkcií na osemnást' sa podarilo zvolit' štrnástich „rodinných" úradníkov, čo predstavovalo $82,35 \% .{ }^{55} \mathrm{Na}$ ústrednej administratívnej úrovni za nového zastupujúceho podžupana vybrali otca krstniat Františka Jancsóa Samuela Korotnokyho. Na notariáte riadnym notárom zostal Martin Dobay. Hlavný župan Ján Nepomuk Csáky za podnotára menoval Michala Theőkeho a za zastupujúceho podnotára Korotnokyho zat’a Jozefa Kolacskovszkého. Do rúk riadneho podžupana sa dostal aj celý fiškalát. Na poste fiškála sa udržal Michal Kissóczy a Csáky za podfiškála dosadil pravdepodobne syna Ignáca Vitkóczyho a možno aj Jancsóove krstňa Pavla Vitkóczyho. ${ }^{56}$

Na miestnej úrovni si v prvom okrese svoje pozície udržal riadny slúžny Mikuláš Almássy a zastupujúci slúžny Adam Sváby. Do novej funkcie výbercu daní pre oba dištrikty zvolili druhostupňového Svábyho bratranca Mojžiša Svábyho. V druhom okrese sa zmenili predošlí úradníci. Zastupujúcim slúžnym sa stal Ladislav Görgey, ktorého svokor Gabriel Podhorányi bol synovcom Jancsóovej sestry, a výbercom daní pravdepodobne vel'mi blízky Podhorányiho príbuzný Ján Podhorányi. K výmene funkcionárov došlo aj v tret’om okrese, kde post riadneho slúžneho obsadil Rikolf Berzeviczy a zastupujúceho slúžneho Štefan Nemessányi. Za pokladníka panstva hlavný župan znovu ustanovil Jozefa Horanszkého. ${ }^{57}$

František Jancsó ešte zrejme cielene ovplyvnil výber partnerky budúceho podfiškála Andreja Berzeviczyho, ktorý sa 30. januára 1774 oženil s dcérou Ignáca Vitkóczyho Julianou Vitkóczyovou. ${ }^{58}$ Posilnenie väzieb vo vol'bách 5. septembra 1775 prinieslo pri zvýšení počtu volených i menovaných funkcií oproti predošlej reštaurácii o šest' nových miest takmer identický podiel 82,61 \%. I ked'

54 MV SR, SAL, f. ZCM, i. č. 709, MRKF Spišská Kapitula, k. 269, pag. 38; SZLUHA, ref. 4, s. 160, 394. SZLUHA, ref. 7, s. 548, 549; SZLUHA, ref. 8, Berzeviczy, Berzeviczei és Kakaslomniczi nemes és †báró, tabul'ka VII, IX, XII; Dobay, Dobói, tabul'ka III; Kapy, Kapivári, tabul'ka II; Péchy, Péchújfalusi nemes és †tgróf, tabul'ka XIII, XIV.

55 MV SR, SAL, f. SŽ, i. č. 118 , KP z roku 1772, k. 51, pag. 586, 587; f. ZCM, i. č. 139, MRKF Huncovce, k. 59, pag. 419; i. č. 583, MRKF Pol'anovce, k. 216, pag. 88, 91; i. č. 618, MRKF Slovenská Ves, k. 231, pag. 40; i. č. 827, MRKF Spišský Hrhov, k. 319, pag. 66; i. č. 1057, MRKF Žehra, k. 407, pag. 25; SZLUHA, ref. 4, s. 103, 184, 185.

56 MV SR, SAL, f. ZCM, i. č. 583, MRKF Pol’anovce, k. 216, pag. 88, 91, 94; SZLUHA, ref. 4, s. $184,185$.

57 MV SR, SAL, f. ZCM, i. č. 618, MRKF Slovenská Ves, k. 231, pag. 40; SZLUHA, ref. 4, s. 103, 160, 354, 355; SZLUHA, ref. 7, s. 548, 549.

58 SZLUHA, ref. 8, Berzeviczy, Berzeviczei és Kakaslomniczi nemes és †báró, tabul'ka XI. 
sa dosiahla takmer rovnaká percentuálna účast', počet „rodinných“ úradníkov bol až devätnást', teda vyšší o piatich šl'achticov. I ked' sa vol'by konali priamo v Spišskej Kapitule, zvolili troch evanjelikov, čo predstavovalo $12,5 \% .{ }^{59}$

$\mathrm{Na}$ centrálnej úrovni zostali vo funkciách zastupujúci podžupan Samuel Korotnoky, riadny notár Martin Dobay, prvý podnotár Michal Theőke, druhý podnotár Jozef Kolacskovszky a fiškál Michal Kissóczy. Za nového podfiškála zvolili Andreja Berzeviczyho a čerstvo zriadenú funkciu účtovného dozorcu obsadil synovec Magdy Máriássyovej Michal Máriássy, ktorý sa rok po vol'bách oženil s dcérou Františka Jancsóa.

Na miestnej úrovni sa v prvom okrese udržal riadny slúžny Mikuláš Almássy a zastupujúci slúžny Adam Sváby. Na nový post čiastkového pokladníka zvolili Imricha Doloviczénya a za riadnych prísažných prísediacich Mojžiša Svábyho a Štefana Vitálisa. Ten bol zrejme synom Žofie Máriássyovej, ktorej švagrom bol synovec Jancsóovej sestry Gabriel Podhorányi. V druhom okrese pozíciu zastupujúceho slúžneho získal Matej Bobest, čiastkového pokladníka Jozef Horanszky a riadnych prísažných prísediacich Tomáš Doloviczény a Ján Podhorányi. V tret’om okrese sa pozície rozdelili medzi riadneho slúžneho Ladislava Görgeya, zastupujúceho slúžneho Štefana Nemessányiho a riadneho prísažného prísediaceho Tomáša Theőkeho, ktorý bol bratom Michala Theőkeho. ${ }^{60}$

\section{Obdobie Františka Xavera Máriássyho (1779 - 1783)}

Dňa 6. marca 1776 zomrel František Jancsó. Ked’že Ján Nepomuk Csáky nezvolal bezodkladne reštauráciu, jeho kompetencie dočasne vykonával zastupujúci podžupan Samuel Korotnoky. Neobsadenie úradu trvalo viac ako tri roky, až do reštaurácie 31 . augusta $1779 .{ }^{61}$ Bez d'alších prameňov sa len obtiažne dal vysvetlit taký dlhý časový odstup. Po smrti Jancsóa by sa očakávalo, že po vypísaní volieb sa o miesto riadneho podžupana bude uchádzat' František Xaver Máriássy, syn bývalého podžupana Štefana Máriássyho. V susednej Liptovskej stolici bolo totiž bežné, že po smrti riadneho podžupana nezvolili hned' jeho syna, ale miesto prenechali inému šl'achticovi z nepotistickej siete a až po jeho odstúpení alebo úmrtí post prešiel do rúk syna predošlého riadneho podžupana. František Xaver Máriássy bol síce v rokoch 1762 - 1767 zastupujúcim podžupanom Spišskej stolice, ale súčasne zastával aj post riadneho podžupana Gemerskej stolice. Takéto počínanie sa z hladiska nariadení považovalo za protiprávne, a preto sa Máriássy rozhodol pre kariéru v Gemeri. Zrejme z tohto dôvodu Csáky čakal s vypísaním

59 MV SR, SAL, f. SŽ, i. č. 121, KP z roku 1775, k. 54, pag. 597, 598; f. ZCM, i. č. 1021, MRKF Vyšný Slavkov, k. 393, pag. 64; SZLUHA, ref. 4, s. 246, 306, 394; SZLUHA, ref. 8, Berzeviczy, Berzeviczei és Kakaslomniczi nemes és †báró, tabul'ka XI.

60 SZLUHA, ref. 4, s. 160, 239, 246, 424; SZLUHA, ref. 7, s. 548, 549.

61 MV SR, SAL, f. SŽ, i. č. 125, KP z roku 1779, k. 57, pag. 468-471; SZLUHA, ref. 4, s. 160. 
volieb, pravdepodobne do času, kým sa Máriássy prestane angažovat' v administratíve susedného Gemera. ${ }^{62}$

František Xaver Máriássy však medziobdobie rokov 1776 - 1779 využil na upevnenie zdedenej nepotistickej siete po otcovi. Dňa 6. októbra 1776 sa konala svadba Máriássyho syna Michala Máriássyho s dcérou nedávno zosnulého riadneho podžupana Annou Jancsóovou. Práve Annina matka bola druhostupňovou sesternicou Martina Dobaya a zároveň sestrou Antona Jancsóa. Do príbuzenstva sa touto svadbou dostal aj Matej Bobest, ktorého nevlastná sestra bola druhostupňovou sesternicou Žigmunda Görgeya, ktorého manželka bola druhostupňovou sesternicou Anninej matky. Manželským zväzkom sa k rodine pričlenil aj Žigmund Jekelfalussy, ktorého sesternica mala za manžela Anninho bratranca. Niekedy medzi rokmi 1776 - 1779 sa konala aj svadba Jozefa Kolacskovszkého s Františkou Korotnokyovou, pričom Kolacskovszkého svokra bola dcérou Heleny Berzeviczyovej, ktorej švagor bol manželom sestry Františka Xavera Máriássyho. Tesne po vol'bách 5. septembra 1779 sa krstnou matkou vnučky Františka Xavera stala manželka Jána Baptistu Johnyho. ${ }^{63}$

Vd’aka zdedeným príbuzenským zväzkom, ale aj novovybudovaným sa 31. augusta 1779 podiel „rodinných“ úradníkov dostal na úroveň 86,96 \%. Pozitívny výsledok sa dosiahol i napriek tomu, že podiel zvolených evanjelikov už bol pät' šl'achticov, čo znamenalo $20,83 \%{ }^{64} \mathrm{Na}$ centrálnej úrovni sa zastupujúcim podžupanom stal Martin Dobay. Hlavný župan za riadneho notára priamo menoval Michala Theökeho, ktorého strýko bol švagrom sestry Františka Xavera Máriássyho; za prvého podnotára Jána Berzeviczyho, ktorého švagor bol Máriássyho bratrancom; a za druhého podnotára Antona Jancsóa. Stavy schválili aj d’alších županových kandidátov na fiškála Andreja Berzeviczyho, ktorého svokra bola neterou Alžbety Horváthovej-Kissevithovej, ktorej syn bol švagrom Máriássyho sestry; a na podfiškála Jozefa Kolacskovszkého. Za všeobecného

62 MV SR, SAL, f. SŽ, i. č. 108, KP z roku 1762, k. 44, pag. 316; i. č. 113, KP z roku 1767 , k. 47, pag. 414; f. ZCM, i. č. 170, MRKF Chrast' nad Hornádom, k. 71, pag. 39, 42, 43, 46, 49, 107.

63 MV SR, SAL, f. ZCM, i. č. 170, MRKF Chrast' nad Hornádom, k. 71, pag. 67; SZLUHA, ref. 4, s. 28, 112, 113, 124, 125, 160, 164, 165, 184, 185, 246, 247; SZLUHA, ref. 7, s. 548, 549. SZLUHA, ref. 8, Berzeviczy, Berzeviczei és Kakaslomniczi nemes és †báró, tabul'ka II, IX; Dobay, Dobói, tabul'ka III.

64 MV SR, SAL, f. ZCM, i. č. 24, MRKF Brutovce, k. 9, pag. 37; i. č. 170, MRKF Chrast' nad Hornádom, k. 71, pag. 77, 191; i. č. 410, MRKF Lubica, k. 154, pag. 185; i. č. 620 MRKF Slovenská Ves, k. 231, pag. 246, 252; i. č. 827, MRKF Spišský Hrhov, k. 319, pag. 66, 73; i. č. 914, MRKF Toporec, k. 351, pag. 27; SZLUHA, ref. 4, s. 62, 63, 103, 131, 165, 184, 185, 246, 306, 419, 424; SZLUHA, ref. 8, Berzeviczy, Berzeviczei és Kakaslomniczi nemes és †báró, tabul'ka II, III, VI, XI; Dobay, Dobói, tabul'ka III. 
pokladníka zvolili Jána Baptistu Johnyho a účtovného dozorcu Michala Máriássyho.

Na lokálnej úrovni v prvom okrese potvrdili riadneho slúžneho Mikuláša Almássyho, ktorého švagriná bola švagrinou Františka Xavera Máriássyho, zastupujúceho slúžneho Adama Svábyho. Jeho matka bola tretou ženou strýka Máriássyho švagra, a čiastkového pokladníka Imricha Doloviczényho, ktorého manželka bola zrejme vo vel'mi blízkom pokrvnom vzt’ahu s Máriássym. Ako nových prísažných prísediacich zvolili Štefana Vitálisa, ktorého matka bola Máriássyho sesternicou; a Wolfganga Berzeviczyho, ktorého teta bola svokrou Máriássyho sestry. V druhom okrese potvrdili zastupujúceho slúžneho Mateja Bobesta. Novými úradníkmi sa stali prísažní prísediaci, brat Michala Theőkeho Tomáš Theőke a Jozef Máriássy, ktorého starý otec bol bratrancom riadneho podžupana. V tret’om okrese sa udržal riadny slúžny Ladislav Görgey, ktorého teta bola manželkou Alexandra Mattyasovszkého, ktorý bol Máriássyho švagrom. Ako noví úradníci pribudli čiastkový pokladník, Máriássyho synovec, Juraj Gundelfinger a prísažní prísediaci Žigmund Jekelfalussy a predpokladaný brat alebo bratranec Michala Theőkeho Baltazár Theöke. ${ }^{65}$

\section{Obdobie riadneho podžupana Michala Theőkeho (1783 - 1785)}

František Xaver Máriássy zomrel 6. januára 1783 a hlavný župan Ján Nepomuk Csáky znovu okamžite nezvolal vol’by a dočasne stolicu viedol zastupujúci podžupan Martin Dobay. Csáky reštauráciu zvolal až po deviatich mesiacoch na 15. októbra $1783 .{ }^{66}$ Vol'by sa konali v biskupskom paláci v Spišskej Kapitule a po zverejnení Tolerančného patentu evanjelickí šlachtici právom očakávali, že znovu získajú svoje zastúpenie medzi stoličným úradníctvom. Preto sa po jeho vydaní aj v ostatných konfesionálne zmiešaných stoliciach zvýšila účast' nekatolíckych šl'achticov. V prípade Spiša stúpol počet evanjelikov v administratíve na devät', čo predstavovalo $37,5 \%$ a znamenalo skoro zdvojnásobenie oproti posledným vol'bám. ${ }^{67}$

65 SZLUHA, ref. 4, s. 103, 131, 149, 238, 239, 246, 247, 264, 265, 354, 394, 395, 424; SZLUHA, ref. 8, Berzeviczy, Berzeviczei és Kakaslomniczi nemes és †báró, tabul'ka II, III,VI, VII, IX; Kapy, Kapivári, tabul'ka II.

MV SR, SAL, f. SŽ, i. č. 129, KP z roku 1783, k. 59, pag. 213-216; f. ZCM, i. č. 170, MRKF Chrast' nad Hornádom, k. 71, pag. 191.

67 MV SR, SAL, f. ZCM, i. č. 365, MEF Levoča, k. 138, pag. 143; i. č. 617, MRKF Slovenská Ves, k. 231, pag. 106; i. č. 618, MRKF Slovenská Ves, k. 231, pag. 48; i. č. 619, MRKF Slovenská Ves, k. 231, pag. 53; i. č. 827, MRKF Spišský Hrhov, k. 319, pag. 66; i. č. 1021, MRKF Vyšný Slavkov, k. 393, pag. 80; SZLUHA, ref. 4, s. 62, 131, 153, 165, 184, 185, 238, 240, 246, 264, 303, 306; SZLUHA, ref. 8, Berzeviczy, Berzeviczei és Kakaslomniczi nemes és †łbáró, tabul'ka VI, VII, XI. 
Zvýšenie počtu evanjelikov zákonite spôsobilo, že podiel „rodinných“ úradníkov nového riadneho podžupana Michala Theőkeho dosiahol iba 52,17 \%, pričom oproti prechádzajúcim vol'bám išlo temer o $30 \%$ prepad. Vyhliadky Theőkeho na udržanie si pevnej nepotistickej siete boli slabé, pretože ani otec a ani jeho starý otec nezastávali post riadneho podžupana. $\mathrm{V}$ dôsledku toho sa Theőke nemohol opriet' o systematicky formovanú siet' spriaznených úradníkov. Rod sa navyše zarad'oval so svojím majetkom iba medzi bohatších zemanov a sobášne zväzky sa preto uzatvárali hlavne s približne rovnako zámožnými rodmi. Priaznivý výsledok vo vol'bách sa dosiahol predovšetkým vd’aka spriaznenosti s rodinou Františka Xavera Máriássyho.

Na centrálnej úrovni sa novým zastupujúcim podžupanom stal Tomáš Mattyasovszky, ktorého bývalá švagriná bola tetou Zuzany Görgeyovej, ktorá bola manželkou bratranca Zuzany Theökeovej, manželky Michala Theőkeho. Na notariáte hlavný župan priamo vymenoval riadneho notára Andreja Berzeviczyho, ktorého svokra bola neterou Theőkeho starej matky; a prvého podnotára Žigmunda Jekelfalussyho, ktorého strýko mal za manželku Máriu Görgeyovú, ktorá bola sesternicou otca Heleny Görgeyovej, pričom Helena bola Theőkeho tetou. Za fiškála si stavy zvolili Jozefa Kolacskovszkého, ktorého svokra bola švagrinou Žigmunda Theőkeho, ktorý bol strýkom Theökeho manželky. ${ }^{68}$

Na miestnej úrovni v prvom okrese zvolili za riadneho slúžneho Jána Berzeviczyho, ktorého švagor bol bratrancom Magdy Máriássyovej, ktorá bola švagrinou strýka Michala Theökeho; a za čiastkového pokladníka Imricha Doloviczénya, ktorého manželka bola pravdepodobne príbuznou Jozefa Horanszkého, pričom jeho švagor Žigmund Theőke bol bratrancom Theőkeho manželky. V druhom okrese prevzal post riadneho slúžneho synovec Magdy Máriássyovej Michal Máriássy a zastupujúceho slúžneho Jozef Máriássy, ktorého starý otec bol bratrancom Magdy Máriássyovej.

V tret'om okrese medzi rodinu riadneho podžupana patril riadny slúžny Juraj Gundelfinger, Magdin synovec; čiastkový pokladník Mikuláš Petróczy, Theőkeho švagor; a prísažní prísediaci Baltazár Theőke, ktorý bol zrejme Theőkeho bratrancom a Ignác Vitkóczy, ktorého matka bola neterou Alžbety Horváthovej-Kissevithovej, ktorá bola Theőkeho starou matkou. ${ }^{69}$

68 SZLUHA, ref. 4, s. 102, 103, 112, 113, 149, 164, 165, 184, 264, 265, 392-394; SZLUHA, ref. 8, Berzeviczy, Berzeviczei és Kakaslomniczi nemes és †báró, tabul'ka XI.

69 MV SR, SAL, f. ZCM, i. č. 1021, MRKF Vyšný Slavkov, k. 393, pag. 80; SZLUHA, ref. 4, s. 102, 103, 131, 149, 238, 239, 246, 247, 303, 392-395; SZLUHA, ref. 7, s. 214; SZLUHA, ref. 8, Berzeviczy, Berzeviczei és Kakaslomniczi nemes és †báró, tabul'ka VI, VII, IX; Kapy, Kapivári, tabul'ka II. 


\section{Oslabenie vplyvu nepotizmu v roku 1790}

V čase jozefínskej reformy uhorských administratívnych jednotiek si Spišská stolica zachovala vd’aka svojej rozlohe územnú integritu na rozdiel od menšej Liptovskej, Oravskej, Turčianskej a Zvolenskej stolice, kde došlo k zlúčeniu dvoch pôvodne samostatných stolíc. Po odvolaní reforiem a nástupe Leopolda II. sa mohlo na Spiši zdat', že z hl'adiska nepotizmu nedôjde k žiadnym zmenám. Avšak potvrdil sa podobný trend ako na Liptove, ked' sa už k postu riadneho podžupana nedostali šlachtici z členov rodu Görgey, Jancsó a Máriássy, ktorí určovali predošlý vývoj.

Vol'by sa konali 13. apríla 1790 v prítomnosti hlavného župana Jána Nepomuka Csákyho, ktorý predostrel trojčlennú kandidátnu listinu na riadneho podžupana. V zozname sa nachádzali mená dvoch katolíkov Martina Dobaya a Mikuláša Almássyho. Evanjelickú zložku privilegovaného obyvatel'stva reprezentoval Imrich Horváth-Stansith. Ked’že sa v Uhorsku ako všeobecný zvyk zaužívala štvorčlenná kandidátka, objavili sa okamžite protesty a vyvstala požiadavka na d’alšieho evanjelika. Nakoniec sa župan rozhodol pre veterána vojen Jozefa II. proti Osmanskej ríši Andreja Berzeviczyho. ${ }^{70}$

Prítomné stavy si spomedzi uvedených mien vybrali Andreja Berzeviczyho, ktorý vôbec nežil na území Spišskej stolice, ale v susednej Šarišskej stolici v Brezovici. Vol'by prekvapujúco nevyhral Imrich Horváth-Stansith, najbohatší kandidát a prasynovec niekdajšieho podžupana zo začiatku 18. storočia. Za zdanlivo prekvapujúcim výsledkom zrejme stála skutočnost', že v elektoráte mali stále rozhodujúci vplyv l’udia blízki Görgeyovcom, Jancsóovcom a Máriássyovcom. Berzeviczy bol totiž manželom Júlie Vitkóczyovej, ktorej otec Ignác Vitkóczy bol v rokoch 1754 - 1767 riadnym slúžnym tretieho okresu a Júliiným krstným otcom bol niekdajší podžupan Ezechiel Görgey. Navyše, Júliini súrodenci mali za krstného otca tiež niekdajšieho podžupana Františka Jancsóa. ${ }^{71}$

Pri vol'be zastupujúceho podžupana župan Ján Nepomuk Csáky predostrel na zvolenie len dvoch katolíkov Mikuláša Almássyho a niekdajšieho riadneho podžupana Michala Theökeho. V tomto prípade si evanjelické stavy presadili Imricha Horvátha-Stansitha, čím vlastne dosiahli, že najdôležitejšie úrady obsadili evanjelici. No napriek tomu sa celkovo zvolilo len šest' šl'achticov, čo predstavovalo $33,33 \%$ podiel evanjelikov na celkovom zložení úradníckeho

70 MV SR, SAL, f. SŽ, i. č. 146, KP z roku 1790, k. 67, pag. 64-67.

71 MV SR, SAL, f. SŽ, i. č. 100, KP z rokov $1754-1755$, k. 40, pag. 37; i. č. 113, KP z roku 1767, k. 47, pag. 415; f. ZCM, i. č. 1021, MRKF Vyšný Slavkov, k. 393, pag. 60, 62, 64, 70, 80; SZLUHA, ref. 4, s. 152, 153; SZLUHA, ref. 8, Berzeviczy, Berzeviczei és Kakaslomniczi nemes és †báró, tabul'ka XI. 
aparátu, ${ }^{72}$ čo bolo menej ako pri posledných vol'bách v roku 1783 a zd’aleka nedosahoval úroveň zo začiatku 18. storočia.

Andrej Berzeviczy a ani jeho rodičia sa nikdy predtým neangažovali v správe Spišskej stolice, a preto nemal ani vybudované nejaké nepotistické siete, čo sa prejavilo aj v podiele jeho „rodinných“ úradníkov iba na úrovni 39,3 \%, čím sa znova znízil vplyv nepotizmu oproti vol'bám v roku 1783. Zároveň sa ale potvrdil tento trend aj v Liptovskej stolici, kde rovnako skončilo „zlaté obdobie“ nepotizmu. Na dôvažok, Andrej Berzeviczy nadobudol priaznivé percentuálne číslo nie z vlastnej iniciatívy, ale iba vd'aka tomu, že sa jeho brat Ján Berzeviczy v roku 1787 oženil s Cecíliou Péchyovou. ${ }^{73}$

Z centrálnych úradov sa pod vplyv Andreja Berzeviczyho dostal takmer celý notariát, ked’ župan za riadneho notára priamo vymenoval Žigmunda Jekelfalussyho, ktorého bratranec bol švagrom Žofie Úszovej a jej manžel bol strýkom Cecílie Péchyovej. Za prvého podnotára župan ustanovil L’udovíta Almássyho, ktorého otec bol bratrancom Mikuláša Petróczyho, ktorého švagriná Mária Görgeyová bola dcérou synovca Ezechiela Görgeya. Pričom Ezechiel Görgey nebol len krstným otcom Júlie Vitkóczyovej, ale aj manželom Cecíliinej tety. Za všeobecného pokladníka si stavy zvolili Ladislava Görgeya, ktorý bol synom Cecíliinej tety. ${ }^{74}$

Na lokálnych postoch medzi „rodinných“ úradníkov Andreja Berzeviczyho patril riadny slúžny prvého okresu Jozef Máriássy, ktorého prateta bola manželkou Gabriela Podhorányiho, ktorý bol zrejme bratrancom Štefana Podhorányiho, švagra Cecílie Péchyovej. K ovládnutiu správy celého okresu došlo v tret’om okrese, odkial' pochádzala Berzeviczyho manželka. Riadnym slúžnym sa stal Michal Máriássy, ktorého švagor bol Cecíliiným bratrancom, zastupujúcim slúžnym Berzeviczyho švagor Ignác Vitkóczy a čiastkovým pokladníkom Mikuláš Petróczy. Za prísažných prísediacich zvolili Ignáca Máriássyho, ktorý bol bratom Michala Máriássyho a zároveň švagrom Cecíliinho bratranca. Za druhého prísažného prísediaceho určili Alexandra Theőkeho, ktorého svokor bol synovcom Ezechiela Görgeya. ${ }^{75}$

72 MV SR, SAL, f. ZCM, i. č. 18, MRKF Bijacovce, k. 8, pag. 3; i. č. 170, MRKF Chrast' nad Hornádom, k. 71, pag. 32, 77; i. č. 583, MRKF Pol'anovce, k. 216, pag. 88, 91, 94; i. č. 841, MRKF Spišský Hrušov, k. 322, pag. 138; i. č. 914, MRKF Toporec, k. 351, pag. 27; SZLUHA, ref. 4, s. 28, 62, 63, 103, 165, 184, 185, 246, 247, 282, 303, 393, 424; SZLUHA, ref. 7 , s. 134.

73 SZLUHA, ref. 8, Berzeviczy, Berzeviczei és Kakaslomniczi nemes és †báró, tabul'ka XI.

74 MV SR, SAL, f. ZCM, i. č. 15, MRKF Bijacovce, k. 7, pag. 12; i. č. 619, MRKF Slovenská Ves, k. 231, pag. 54; SZLUHA, ref. 4, s. 102, 103, 165, 302, 303, 392, 393; SZLUHA, ref. 8, Berzeviczy, Berzeviczei és Kakaslomniczi nemes és †báró, tabul'ka XI; Péchy, Péchújfalusi nemes és †̣róf, tabul'ka X; Úsz, Úszfalvi, tabul'ka II.

75 SZLUHA, ref. 7, s. 548, 549; SZLUHA, ref. 8, Péchy, Péchújfalusi nemes és †gróf, tabul'ka 
Pri retrospektívnom pohl'ade na nepotistické väzby v správe Spišskej stolice vidiet' podstatný rozdiel oproti Liptovskej stolici, ked’že na Spiši vzájomné väzby medzi úradníkmi neboli v drvivej miere $\mathrm{v}$ rovine najužšej rodiny $\mathrm{v}$ podobe bratrancov, synovcov, zat’ov, švagrov či krstných synov. Na základe zachovaných matričných záznamov sa dá vyslovit’ aj záver, že ani systém „cirkevných“ úradníkov sa na Spiši natol'ko nerozvinul ako v Liptovskej stolici. Uvedené javy jednoznačne súviseli s chýbajúcou pevnou sobášnou alianciou medzi rodmi Görgey a Máriássy, ktoré svojím významom zodpovedali pevne aliančne spojeným liptovským rodom Okolicsányi a Szentiványi.

V prvej tretine 18. storočia v prostredí Spišskej stolice ani jeden z riadnych podžupanov systematicky nebudoval nepotistickú siet' a každý sa spoliehal iba na existujúce široké príbuzenstvo. Pritom očakávali, že pri vol'bách bude určite zvolený niekto z ich pokrvných príbuzných. Ked' sa $\mathrm{v}$ roku 1731 podžupanom stal Štefan Máriássy, zrejme nikto netušil, že založí úradnícku dynastiu, ktorú by nemalo ohrozit' ani zvolenie iného ako Máriássyovského rodového príslušníka.

Z hladiska budúceho nepotizmu dôležitý okamih pre Štefana Máriássyho stelesňovala svadba jeho najstaršej dcéry Magdy Máriássyovej s Gašparom Jancsóom, ktorý pochádzal z klientelistického rodu hlavných spišských županov Csákyovcov. Vd’aka tomu záujmy Máriássyho a neskôr i jeho syna skryte podporovali aj aristokratickí Csákyovci s najväčším šlachtickým pozemkovým vlastníctvom na Spiši. Premysleným sobášom druhej Máriássyho dcéry Júlie Máriássyovej s Ladislavom Mattyasovszkým sa okamžite zdvojnásobilo percentuálne zastúpenie „rodinných“ úradníkov. Prostredníctvom Mattyasovszkých sa do okruhu Máriássyho pokrvného príbuzenstva dostali predošlí spišskí riadni podžupani z Görgeyovcov. Ked’ prvý manžel Magdy Máriássyovej zomrel, vydala sa za Alexandra Berzeviczyho, čo spôsobilo, že sa nakoniec dôležitost' Mattyasovszkých pre Máriássyovcov začínala oslabovat' a pozvol'ne ich nahradili Berzeviczyovci.

Negatívne vnímanie nepotizmu zo strany štátu bolo nepriame, pretože voči nemu priamo nezasahoval. Od druhej polovice 18. storočia narastal objem a náročnost' písomnej agendy, ktorú mohli dôkladne zvládat' iba vzdelaní úradníci. To bola jedna z foriem nepriameho potláčania nepotizmu, ked’ župan pri menovaní nových úradníkov začal prihliadat' na vzdelanost' bez ohl'adu na rodinné väzby. Pre Královskú miestodržitel'skú radu nepotizmus nepredstavoval zásadný problém, pokial' to priamo neohrozovalo výkon samosprávnych úloh stolice, ktoré sa dostávali pod stále väčší drobnohl'ad najmä vo vojenskej a finančnej oblasti. V mnohých prípadoch dokonca mohlo miestodržitel'stvo vnímat' nepotizmus ako pozitívny jav. Zabezpečoval totiž dlhodobejšiu kontinuitu jedného

X; Szinyei Merse (Merse), Szinyei, tabul'ka II. 
stoličného úradníka, čím sa jeho pozícia približovala k postaveniu štátneho, ktorý bol dlhodobo zamestnancom štátnej inštitúcie.

Nepotizmus sa stal problematickým pre Král'ovskú miestodržitel'skú radu iba vtedy, ked' to ohrozovalo štátne záujmy. Pri rastúcich požiadavkách na charakter stoličnej správy sa miestodržitel'stvo nemohlo zmierit's tým, že by bol konkrétny šlachtic $\mathrm{v}$ tom istom čase úradníkom viacerých stolíc. $\mathrm{V}$ takom prípade nemohol dostatočne spíňat' zverené úlohy a zákonite musel zanedbávat' post $\mathrm{v}$ jednej zo stolíc. V tomto prípade bola regionálna šlachta; na rozdiel od hlavných županov a ostatnej aristokracie, ktorá vo svojich rukách kumulovala viaceré titulárne či skutočné funkcie a hodnosti; diskriminovaná. Nariadenia o zákaze kumulovania stoličných úradov sa v Spišskej stolici priamo dotkli Františka Xavera Máriássyho, ktorý v rokoch 1762 - 1767 zastával post zastupujúceho podžupana, a zrejme v roku 1765 sa uchádzal aj o stoličku riadneho podžupana Gemerskej stolice a bol úspešný. Máriássy vedel, že stolice zvyčajne neodovzdávali Král'ovskej miestodržitel'skej rade zoznamy úradníkov okamžite a aj po ich obdržaní istú dobu trvalo, kým sa po kontrole na miestodržitel'stve prišlo na skutočnost', že konkrétny úradník porušuje prijaté snemové zákony a panovnícke nariadenia. Preto až po upozornení od nadriadeného miestodržitel’stva sa Máriássy počas spišských volieb v roku 1767 vzdal d’alšej kandidatúry na zastupujúceho podžupana, ked’že úrad riadneho podžupana v susednom Gemeri bol predsa len prestížnejší.

* Táto štúdia vznikla v rámci projektu APVV-17-0398 Na ceste $k$ modernej spoločnosti. Tri storočia novoveku a VEGA č. 2/0086/20 Administrativa raného novoveku v zrkadle štátnej, stoličnej, panskej a mestskej správy.

\section{NEPOTISMUS IM BERICHT DES KOMITATS ZIPS IN DEN JAHREN $1711-1785$}

\section{TOMÁŠ J A N U R A}

Im Bericht des Komitats Zips waren die gegenseitigen Bindungen zwischen den Beamten zum größten Teil in der Ebene der engsten Familie sowie es im Komitat Liptau der Fall war. Anhand der Eintragungen beim Standesamt wurde auch das System der ,kirchlichen“ Beamten zu Zips nicht im gleichen Ausmaß wie in Liptau entwickelt. Die genannten Phänomene hingen eindeutig mit der fehlenden festen Eheallianz zwischen den Geschlechtern Görgey und Máriássy zusammen, die durch ihre Bedeutung den durch eine Allianz fest verbundenen Liptauer Geschlechtern Okolicsányi und Szentiványi entsprachen. 
In Zips gründete nur Stephan Máriássy eine Beamtendynastie. Im Hinblick auf den künftigen Nepotismus war die Hochzeit seiner ältesten Tochter Magda Máriássy mit Gaspar Jancsó, der aus dem Geschlecht der Hauptgespane Csáky stammte, von Bedeutung. Durch die überlegte Eheschließung der zweiten Máriássys Tochter, Júlia Máriassy mit Ladislav Mattyasovsky, wurde sofort die prozentuelle Vertretung der „familiären" Beamten verdoppelt. Nachdem der erste Gemahl von Magda Máriássy gestorben war, heiratete sie Alexander Berzeviczy, was zur Folge hatte, dass das Geschlecht Mattyasovszky für Máriássy an Bedeutung verlor und allmählich durch das Geschlecht Berzeviczy ersetzt wurde.

Mgr. Tomáš Janura, PhD.

Historický ústav SAV

P. O. Box 198, Klemensova 19, 81499 Bratislava

e-mail: histjanu@savba.sk 